\title{
NOBLEZA Y HONOR: EL PATRONATO ECLESIÁSTICO DE LA CASA DE TORENO EN LA ASTURIAS DEL ANTIGUO RÉGIMEN
}

\author{
POR \\ JuAN DÍAZ AlVAREZ ${ }^{1}$ \\ Universidad de Oviedo
}

\begin{abstract}
RESUMEN:
El ascenso de la casa de Queipo, condes de Toreno desde 1657, fue posible a sus preeminencias sociales, económicas, políticas y honoríficas, dentro y fuera de Asturias. Este éxito se sustenta en dos elementos: los servicios a la Corona y la promoción de algunos de sus miembros en la Iglesia, y en una acertada política matrimonial exogámica. Esta notoriedad se publicitó a través del patronato eclesiástico, que comienzan a forjar en el Principado desde los albores del siglo XVI y se consolida en la centuria posterior, ampliándose a otras regiones del reino (León, Madrid, Sevilla o La Rioja), dada la anexión de diversos mayorazgos. La presentación de beneficios curados y simples se complementa con la fundación de capellanías y obras pías, que da lugar a una tupida red de relaciones, en las que no fueron ajenos los conflictos beneficiado-patrón.
\end{abstract}

PALABRAS CLAVE: patronato; fundaciones; beneficios eclesiásticos; capellanías; Asturias.

\section{NOBILITY AND HONOUR: THE ASTURIAN ECCLESIASTICAL PATRONAGE OF THE EARLDOM OF TORENO DURING ANCIEN RÉGIME}

\begin{abstract}
:
The ascent of the Queipo's House, earls of Toreno since 1657, was possible to their social, economic, political and honorific preeminence's in Asturias. This success is sustained in two elements: the services to the Crown and the promotion of some of their members in the Clergy, and in a guessed right exogamous matrimonial policy. This reputation was publicized across the ecclesiastic patronage, which they begin to forget in Asturias from the whiteness of the century XVI and it is consolidated in the later century, being extended to other regions of the kingdom (León, Madrid, Sevilla and La Rioja), given the annexation of diverse primogenitures. The presentation of cured and simple benefits complements itself with the foundation of chaplaincies, which gives place to a thick network of relations, in which the conflicts were not foreign beneficiary-patron.
\end{abstract}

KEY WORDS: Patronage; Foundations; Benefices; Chaplaincies; Asturias.

COMO CitAR ESTE ARtículo / CitATION: Díaz Álvarez, J. 2017. «Nobleza y honor: el patronato eclesiástico de la Casa de Toreno en la Asturias del Antiguo Régimen». Hispania Sacra 69, 140: 579-595. doi: 10.3989/hs.2017.036

Recibido/Received 05-05-2015

Aceptado/Accepted 14-05-2015

Morir no siempre supone dejar de existir. El recuerdo colectivo del finado por parte de sus parientes, lo más habitual por propia iniciativa a través de la estipulación de misas por su alma y la de sus deudos, con las que acortar su estancia en el Purgatorio, fue una vía habitual entre la

1 diazaljuan@uniovi.es Profesor Ayudante Doctor, Departamento de Historia (Área de Historia Moderna) / ORCID iD: http://orcid. org/0000-0003-1860-3291 sociedad estamental del Antiguo Régimen. Aniversarios, novenarios, fundación de capellanías, obras pías y de beneficencia contribuyeron a acortar la estancia de expiación de los pecados terrenales antes del ascenso al cielo; pero también supuso un mero acto propagandístico de la memoria del fundador. En una sociedad jurídicamente privilegiada la experiencia de la muerte suponía, en los casos de los miembros más relevantes de la comunidad, la publicitación de la Casa. 


\section{HACIA UN ESTADO DE LA CUESTIÓN}

El estudio del patronato eclesiástico tiene una mayor tradición desde la óptica de la Historia del Arte, la promoción de construcciones religiosas de mayor o menor relevancia estética. Sin disminuir su importancia significativa y expresiva, pues no deja de reflejar la cara más externa de la preeminencia social de los promotores, laicos o religiosos, me interesa abordar el estudio desde una perspectiva social y cultural, esto es, qué supuso la constitución de un patronato de legos, en el que la máxima aspiración es el derecho de presentación sobre los beneficios curados y simples de iglesias parroquiales, así como la fundación de capillas, capellanías y obras pías. La carga patrimonial y de control familiar será fuerte, pero la autoridad sobre los beneficios eclesiásticos supondrá el dominio sobre una parte de la propiedad eclesiástica, y un complemento económico para las economías nobiliarias.

Sobre estas cuestiones contamos con diversas apreciaciones. Desde una óptica jurídica, Clavero ve en la creación de capellanías un método más para la disposición de pequeños vínculos ${ }^{2}$; desde una perspectiva familiar destaca la visión de Pro Ruiz, ${ }^{3}$ en la que incide también Atienza Hernández, a quien le molesta lo desatendido que se encuentra este objeto de estudio a pesar de las importantes implicaciones que tuvo en la sociedad. ${ }^{4}$ La misma queja expresa Soria Mesa al evaluar la historiografía sobre las oligarquías urbanas, haciendo hincapié en la falta de estudios acerca de las capellanías como un elemento importante en la formación de los patrimonios oligárquicos, así como en la creación de redes de relaciones y de poder alrededor del acceso al estamento eclesiástico, e incide en la relevancia que cobran como medio de ascenso social. ${ }^{5}$

Estos aspectos han sido tratados por diversos autores desde una órbita regional o local. La trascendencia social y honorífica en el cursus honorum de la familia, en su escalada estamental dentro del entramado urbano, la vuelve a manifestar Herreros Moya para el caso cordobés, las mismas tendencias ve Arroyo Vozmediano para Calahorra, donde también entra en juego la sede episcopal y su cabildo como punto fundamental de roces y conflictos. Ramos Cobano observa esta realidad en el caso particular de una familia: los Cepeda, en la que la provisión de beneficios eclesiásticos o la presentación de una capellanía no deja de entrañar solidaridades familiares con respecto a aquellos que no estaban destinados a heredar el vínculo paterno, como un modo de mantenerlos. Sin obviar la función socioeconómica de las capellanías entre la nobleza navarra, Orduña Portus vincula estas prácticas con las mentalidades y lo que a ellas rodean entorno a la muerte, como elemento prestigioso y simbólico. ${ }^{6}$

Íntimamente relacionado con el ansia del reconocimiento social y la ostentación de honores dentro de los recintos sagrados, están los medios utilizados por la aristocracia para conseguir sus fines. Una, la más lógica y pacífica, es

\footnotetext{
2 Clavero 1989: 172 y s.

3 Pro Ruiz 1989: 585-602.

4 Atienza Hernández 1990: 411-458.

5 Soria Mesa 2000: 192; ibídem 2002: 135-148.

6 Arroyo Vozmediano 2008: 189-220; Ramos Cobano 2011: 397418; Herreros Moya 2012: 111-141; Orduña Portus 2012: 583-622.
}

la fundación de capillas y capellanías, como he apuntado, pero también la de cenobios; otra, es más conflictiva y se relaciona con la usurpación de los derechos de patronato regio de iglesias parroquiales y conventos. En este campo, la conflictividad entre la aristocracia y diversas instituciones eclesiásticas, si bien restringido al territorio gallego, puede leerse en la contribución de Presedo Garazo, circunscrito a las postrimerías del medievo y décadas siguientes, cuando a las cuestiones honoríficas hay que sumar las económicas, pues fue cuando comienzan a confeccionarse y consolidarse los patrimonios nobiliarios, sirviéndose para ello de este tipo de prácticas. ${ }^{7}$ Por su parte, Atienza López ofrece visiones de conjunto sobre la fundación de establecimientos monacales con la premisa de reserva de su patronato para la nobleza, pero también su apropiación por medios poco lícitos. ${ }^{8}$

El sistema beneficial del patronato de legos va mucho más allá de las cuestiones sociales, económicas y honoríficas. Su estudio no deja de reproducir un sistema privilegiado que reclamó para sí la Corona desde los Reyes Católicos: el derecho de presentación de las mitras de las diócesis, como un peldaño más de la Monarquía en el que sustentar la centralización y construcción el Estado moderno, como el mismo Atienza insinúa; y, en este sentido, el patronato vinculado al grupo social nobiliario no deja de ser una reproducción del regio. ${ }^{9}$ Lo jurídico, lo social, lo económico y las mentalidades se entremezclan en los trabajos debidos a las plumas de Catalán Martínez y de Barrio Gozalo, quienes se adentran en las implicaciones del sistema beneficial en la España de la Edad Moderna, heredero del medievo, y la estructuración del bajo clero, que se verá enredado en un continuo sistema clientelar. No descuidan las consecuencias perniciosas que puede ejercer en la población la presentación de curatos, en muchas ocasiones a favor de personas poco adecuadas, sobre las que no había ningún tipo de control por parte de las diócesis y sus mitrados para comprobar su grado de preparación y ejercer la cura de almas de los feligreses. La presentación de curatos quedaría, pues, subordinada a los intereses particulares de los titulares de tales derechos. ${ }^{10}$ Como precedente, no pueden obviarse las aportaciones del profesor Morgado García, quien trata estas cuestiones desde una perspectiva más regional al circunscribirse a la diócesis gaditana a lo largo de los siglos XVII y XVIII. ${ }^{11}$ En última instancia, hablar de los beneficiados parroquiales supone hacerlo del bajo clero, pero más aún del rural, que del urbano. Visiones regionales, dentro del territorio de la Cornisa Cantábrica, pueden leerse en las contribuciones de los profesores Saavedra, Sobrado Correa y Presedo Garazo, para la Galicia moderna hasta el cambio hacia la cultura jurídica liberal; Rubio Pérez para León, y en la ya citada Catalán Martínez con respecto al País Vasco. Recientemente, Pegerto Saavedra incide desde una perspectiva general en el reino en el mismo campo y cronología. ${ }^{12}$

\footnotetext{
7 Presedo Garazo 2014a: 553-586.

8 Atienza López 2008: 79-116; ibídem 2009: 37-54; ibídem 2010:
} 235-269.

9 Atienza Hernández 1990: 435.

10 Catalán Martínez 1999: 31-63; ibídem 2000; ibídem 2004: 135167; Barrio Gozalo 2001: 73-107; ibídem 2010b.

11 Morgado García 1990: 343-363; ibídem 1996.

12 Saavedra, Sobrado Correa y Presedo Garazo 2013: 93-128; Rubio Pérez 2013: 129-166; Catalán Martínez 2015: 17-56; Saavedra 2016 : 385-412. 
En otro orden de cosas, el patronato de legos no solo rodó alrededor de los derechos de presentación de la red beneficial sustraída a las diócesis, y de capellanes de las múltiples fundaciones pías hidalgas. El grupo nobiliario se hizo valedor, con el consentimiento de la Iglesia, de otras preeminencias en el espacio sagrado: sepulcros, monumentos funerarios y sitiales en lugares privilegiados fueron determinantes en una sociedad basada en el honor y la jerarquización. Estas cuestiones las aborda Presedo Garazo para el caso gallego durante la época de los Austrias. ${ }^{13}$ Asimismo, destacan otras aportaciones clásicas desde una perspectiva más formal y jurídica, como las de González Ruiz o Miguélez, así como el estudio de las fundaciones piadosas desde el instrumento notarial, caso de Fernández Cubeiro. ${ }^{14}$

Desde una perspectiva asturiana, el patronato eclesiástico no es un tema que hubiera cuajado como interés de investigación. Puedo apuntar algunas contribuciones propias. He analizado el patronato del marquesado de Santa Cruz de Marcenado, si bien me centró en el proceso de formación y consolidación a lo largo del siglo XVII; el tema lo retomo más tarde en mi tesis doctoral, teniendo como observatorio las fundaciones de la oligarquía urbana ovetense a lo largo del periodo de los Austrias como un medio más de ascenso social de este grupo sociopolítico ${ }^{15}$, en la línea que expresara Soria Mesa. Este ámbito de estudio también fue seguido, de modo complementario, por Fernández Secades refiriéndose al caso de los Valdés, una de las familias nobiliarias más representativas del Gijón de los siglos XVI y XVII; y, en su tesis, a la oligarquía en la misma villa durante la centuria ulterior. ${ }^{16}$ La profesora Faya Díaz no ha olvidado el tema del patronato, que lo ha abordado desde la conflictividad alrededor de los derechos de presentación y la percepción de diezmos. ${ }^{17}$ Estas apropiaciones serían denunciadas en 1613 por el deán de la catedral de Salamanca Jerónimo de Chirivoga, comisionado por Felipe III para hacer un informe sobre los derechos del Patronato Real en las diócesis ovetense, lucense y astorgana, y las usurpaciones sufridas. ${ }^{18}$

\section{Preeminencia de los Queipo en la Asturias del Antiguo RÉGIMEN}

El condado de Toreno fue el título de Castilla que recibió en 1657 una de las familias más representativas del suroccidente asturiano: los Queipo. Su origen en el concejo de Cangas de Tineo (en la actualidad Cangas del Narcea) puede rastrearse desde la Plena Edad Media, y su vinculación a

\footnotetext{
13 Presedo Garazo 2014b: 409-431.

14 González Ruiz 1950: 475-501; Miguélez 1953; Fernández Cubeiro 1981: 205-215.

15 Díaz Álvarez 2003: 261-290; ibídem 2006a: 137-139 y 157-159; ibídem 2008: 405-440.

16 Fernández Secades 2009: 215-217; Ibídem 2011: 160-163 y 168-171.

17 Faya Díaz 2007: 29-42; Faya Díaz y Anes Fernández 2007: 331-333.

18 Chirivoga, Gerónimo: Averiguaciones hechas por el Deán de Salamanca Don Jerónimo de Chirivoga, a instancias de S. M. de los Monasterios, Prioratos, Abadías, Beneficios que en la Diócesis de Oviedo pertenecen al Real Patronato [Archivo Histórico Nacional (AHN), Códice 1.196 B]. Este documento ha sido estudiado por Fernández Martín 1974 423-458.
}

la villa del municipio ejerciendo como cabeza de bando, junto a los Omaña, desde finales del siglo xv hasta bien entrada la modernidad. El antagonismo entre ambos clanes favoreció su enfrentamiento por hegemonizar y polarizar la vida política local, esto es, acaparar los oficios municipales, primero electivos, luego venales. Las luchas banderizas supusieron la adscripción de otras familias de la hidalguía de la comarca a una u otra facción y están marcadas por fechorías, abuso de poder, coacción, prácticas paraseñoriales, asesinato. Esta necesidad de monopolizar la municipalidad trascendió al intento de los Omaña de hacerse señores de vasallos pretendiendo los cotos del cercano convento de San Juan Bautista de Corias tras la venta de jurisdicciones eclesiásticas llevada a cabo por Felipe II. Los Queipo, que aún no lo eran, se entrometieron con apoyo del consistorio evitándolo, lo que fue contestado con una demanda judicial ante el tribunal de la Inquisición por parte de Ares de Omaña el Prudente contra Juan Queipo de Llano el Mozo en la década de 1570. En el contencioso aflorarían las tropelías que sendas familias se estaban infligiendo desde los albores de la centuria. ${ }^{19}$

La necesidad de dominio no solo se circunscribió a la administración local; el concejo, si bien realengo, disfrutaba de ciertos privilegios jurisdiccionales en el Principado, por lo que la intervención de la Corona, y por ende del corregidor, su representante, era limitada a la hora de ejercer la justicia al mediar la figura del alcalde mayor, nombrado por el corregimiento, si bien acaparado por los Queipo.

La preeminencia de éstos en el municipio, como titulares de regidurías y de escribanías, se reafirmó desde finales del siglo XVI al adquirir el alferazgo mayor no por compra directa al Rey, sino a un particular: don Fernando Osorio de Valdés, caballero de Santiago y señor del coto de Valdunquillo, hijo natural del arzobispo de Sevilla y canciller de Felipe II, don Fernando de Valdés Salas ${ }^{20}$, quien lo había comprado en 1587, vendiéndolo luego al capitán Suero Queipo de Llano en 1595. Entre ambos había un cercano grado de parentesco, dado que la madre del capitán Suero, doña Catalina de Valdés (esposa de Juan el Mozo), era sobrina del arzobispo don Fernando. El linaje tendría una posición privilegiada en el consistorio, dado que el nuevo oficio con calidad de regidor llevaba parejo varios privilegios tales como ejercer el voto en primer lugar tras los jueces, asiento preeminente, alzar el pendón real en las jornadas de la proclamación de los monarcas al trono y ejercer como alférez de las milicias concejiles. ${ }^{21}$

Este protagonismo militar local lo venían desempeñando desde décadas atrás al ser proveídos con una capitanía de milicias, lo que se hacía por nombramiento directo de la Corona a través del delegado regio. Lo ejerció Juan Queipo de Llano el Viejo y desde 1576 su hijo y sucesor Juan el Mozo,

\footnotetext{
19 Álvarez Delgado 2013: 471-497.

20 Sobre este prelado cabe destacar la monografía de G. Novalín 1968

21 Biblioteca Central de la Universidad de Oviedo (BUO), Toreno, caja 43, docs. 4 (Título de alférez mayor perpetuo de Cangas de Tineo a favor de don Fernando Osorio de Valdés, 1587), 5 (Venta del alferazgo de Cangas de Tineo a favor de Juan Queipo de Llano el Mozo, 1595), 7 (Título de regidor de Cangas de Tineo, 1587), 8 (Perpetuación del título de regidor, 1614) y 10 (Título de dos escribanías, una en Cangas de Tineo, otra en Tineo; 1639). Sobre la venta de oficios públicos en la Asturias de los Austrias vid. Faya Díaz 2003: 75-136.
} 
cuya descendencia lo desempeñó de forma ininterrumpida; del último decía el gobernador don Jerónimo Briceño de Mendoza al concederle la merced, era «persona prinçipal, caballero, hijo de algo, de mucha speriençia en las cosas de la guerra por aver en ella servido a Su Magestad». Esta afirmación refiere otra vertiente de los Queipo: sus servicios al Estado, primero en las armas, como parece ser acometió Juan el Mozo, pero también su hijo Suero Queipo, que embarcó a América como capitán «de la gente de mar y guerra» de una armada bajo el mando del capitán general Diego Flórez de Valdés, también cangués y pariente. Pero antes de estos acontecimientos, los titulares del mayorazgo sirvieron a los Reyes Católicos en 1481, contribuyendo a expulsar de Asturias a los condes de Luna, auténticos polarizadores de la política regional y favorecedores de episodios levantiscos contra el poder real; de hecho la enemistad que se habían granjeado los Omaña en el territorio occidental asturiano procedía de estos sucesos tardomedievales, al ser parientes y afines a los Quiñones. También participó Suero Queipo de Llano el Viejo, fundador del vínculo, al lado de Carlos $V$ contra los comuneros entre 1519 y 1521; su hijo, Juan el Viejo, sirvió al Emperador con quinientos hombres "puestos en campaña a su costa» y su nieto, Juan el Mozo, a Felipe II en Valencia en 1568 y en La Coruña en 1589 ante un ataque de corsarios ingleses..$^{22}$

Estos empleos fueron un trampolín para una mayor proyección en el Principado, pero también el ascenso en la Iglesia de don Fernando de Valdés y Llano ( $†$ Madrid, 1639), segundón de Juan el Mozo, al ser presentado a la mitra metropolitana de Granada y a la presidencia del Real y Supremo Consejo de Castilla. Su posición le permitió favorecer a parientes, que servirían en la administración polisinodial del reino y en el clero. Hay que destacar a don Álvaro Queipo de Llano († Málaga, 1662), quien se hace con el mayorazgo de la casa tras el óbito sin descendencia de su hermano mayor el también capitán don Suero Queipo de Llano († Cangas del Narcea, 1633). Bajo el padrinazgo de su tío sirvió como corregidor en Granada, en Madrid y en Málaga; si bien en las dos primeras ciudades lo hizo repetidamente en dos ocasiones; y alcanzó una plaza de consejero en el de Hacienda. Su posición le posibilitó adquirir otro importante oficio venal: el alferazgo mayor del Principado de Asturias, el más importante de la región al ser el primer oficial de la Junta General, foro político que representaba a la municipalidad asturiana. Los servicios de don Álvaro fueron recompensados con sendos títulos de Castilla, el vizcondado de Matarrosa (1646) y el condado de Toreno (1657), denominación que sublimaba al señorío berciano de la familia. Su éxito supuso la ausencia de la familia durante dos generaciones de la región.

Su hijo y heredero, el segundo conde, don Fernando Queipo de Llano y Valdés (Sevilla, 1637-Madrid, 1681), no retornó a la tierra de sus mayores, sí en contadas ocasiones: en su juventud residió un tiempo en el viejo solar cangués, junto a su hermano don Francisco -luego fallecido-, para

22 BUO, Toreno, caja 44, doc. 45: Cédulas con el nombramiento de capitán de la villa y concejo de Cangas de Tineo a favor de Juan Queipo de Llano el Mozo (1585), el capitán Suero Queipo de Llano (1598, 1603 y 1609), el capitán don Suero Queipo de Llano (1621 y 1629), don Álvaro Queipo de Llano (1633), Título de capitán a favor de Suero Queipo de Llano (1581). López Baamonde 2008: 221. tomar estudios antes de trasladarse al colegio mayor de Santa Cruz de la universidad vallisoletana; y más tarde, en 1674, para tomar parte de una Junta General como alférez mayor del Principado. Fue propuesto para varios corregimientos y electo para los de Burgos y Murcia, que rechazó. Residió en la Corte, donde fue nombrado «concertador de privilegios y confirmaciones del Rey" y representante de la Junta General asturiana. ${ }^{23}$ Sería su vástago y sucesor, el tercer conde don Fernando Queipo de Llano y Valdés (Madrid, 1663-Cangas del Narcea, 1718), el que regresó al Principado, y donde matrimonió con una miembro de la nobleza regional, doña Emilia Francisca de Malleza y Doriga († Cangas del Narcea, 1737). El joven aristócrata procedente de la Corte llegaba imbuido de gran prestigio no solo por su pertenencia a la casa de los Queipos, sino también por los servicios de su padre y abuelo. Esta circunstancia fue un valor importante al facilitar matrimonios exogámicos con mujeres de la nobleza andaluza y castellana. El conde don Álvaro casó en dos ocasiones, la primera con doña Ana Mauricia de Lugo Puebla († 1638); la segunda con doña Inés de Zúñiga y Trejo, señora de Valparaíso de Abajo, en 1639. El segundo conde lo hizo con doña Josefa Jiménez de Arellano († Madrid, 1691), titular de la casa de Arnedo, en La Rioja, y cuya familia estaba bien relacionada en la administración central de la Monarquía al ser hija del caballero de Calatrava don Antonio Jiménez de Arellano, fiscal del consejo de Órdenes, sobrina del santiaguista don José González y Uzqueta, miembro del consejo y cámara del Rey, consejero en el de la Santa Inquisición y presidente del de Hacienda; y prima del hijo de éste, el también caballero de Santiago don Juan González de Uzqueta y Valdés, de los consejos de Castilla y de Indias, y miembro de la Junta de Guerra. Gracias a estos enlaces ventajosos el patrimonio del condado de Toreno aumentó no solo en su Asturias de origen, sino que se extendía por tierras de El Bierzo (León), La Rioja, Madrid, Sevilla, Valencia y Granada. ${ }^{24}$

La descendencia del tercer conde se instaló de modo continuado en el Principado, en el solar y nuevo palacio levantado en la villa de Cangas del Narcea en 1689, hasta la primera década del siglo XIX, me refiero a los condes don Fernando Ignacio (Cangas del Narcea, 1698-1778), don Joaquín José (Cangas del Narcea, 1727-1805) y don José Marcelino Queipo de Llano Valdés (Cangas del Narcea, 1757-1808). La participación del heredero de éste, don José María Queipo de Llano Ruiz de Sarabia (Oviedo, 1786-Madrid, 1843), séptimo conde, en los acontecimientos políticos que precipitó la invasión napoleónica, la Guerra de la Independencia, las Cortes de Cádiz y en los ulteriores gobiernos isabelinos, inauguró un nuevo periodo absentista. ${ }^{25}$

${ }^{23}$ BUO, Ms. 66: Casa de Toreno y otras de Asturias y España (sin fecha, $c$. segundo cuarto del siglo XVIII), ff. 40r y v.; López Baamonde 2007: 33-37; Fernández García 2015: 209-218.

24 BUO, Toreno, caja 29, docs. 12 [Matrimonial de Álvaro Queipo de Llano y Ana de Lugo y Puebla (Sevilla, 1635)], 13 [Matrimonial de Álvaro Queipo de Llano e Inés de Zúñiga y Trejo (Madrid, 1639)] y 14 [Matrimonial de Fernando Queipo de Llano y Valdés y Josefa Jiménez de Arellano (Madrid, 1658)].

25 Varela Suanzes-Carpegna 2005; Toreno 2003; Díaz Álvarez 2016: 277-311. 


\section{El patronato de la colegiata de Santa María Magdalena DE CANGAS DEL NARCEA}

\subsection{La fundación: nueva fábrica, conflictos y agravios}

El elemento más destacado del patronato de la casa condal de Toreno fue la fundación y dotación de la nueva iglesia colegial y parroquial de Cangas del Narcea y su clero, por el mencionado prelado, previa merced de Felipe IV. ${ }^{26}$ Este proceso pasó por dos fases. En primer lugar, la averiguación de si la presentación del párroco era de la Corona o no, lo que se demostró a favor de ésta, a pesar de las intromisiones de algunas de las familias más destacadas del concejo al disponer sepulturas y monumentos funerarios en lugares preeminentes sin autorización. De otra parte, la amenaza de ruina del templo de época medieval, y la imposibilidad de contar con los feligreses para su reparación dadas sus exangües rentas, así como la corta congrua del curato. Estos extremos se determinaron a través de dos informaciones Ilevadas a cabo en 1636, una por parte del Rey, a través del alcalde de la Sala de Hijosdalgo de la Real Chancillería de Valladolid, don Gutierre Argüelles de Celles; otra a cargo del ordinario de la diócesis ovetense, cuya sede ocupaba don Antonio de Valdés. Es muy posible que el informe del deán salmantino Jerónimo de Chirivoga sobre el patronato real en la mitra asturiana adelantara el estado lamentable de la iglesia canguesa, así como la limitada renta del párroco, y que fuera el germen de la información, si la Corona tenía la intención de ceder su patronato al arzobispo don Fernando, quien debería hacerse cargo de los gastos que entrañaban las reparaciones de la vetusta iglesia y aportar una renta adecuada al beneficiado parroquial. ${ }^{27}$

Una vez que el monarca extendió su privilegio, la noticia fue recibida positivamente por parte de los notables de la villa de Cangas cuando el capitán Rodrigo Queipo de Llano, sobrino del prelado-presidente, tomó posesión en su nombre, congratulándose y felicitando al nuevo patrón. Algunos de ellos, también informantes en los interrogatorios solicitados por el Rey y el Obispo, hacían referencia a ciertas preeminencias que algunos particulares tenían en la iglesia, sobre todo las que se había arrogado la casa de Omaña, representada por su mayorazgo don Lope, incurriendo en oprobio hacia la Real Casa, más aún cuando lo que se intentaba denunciar era el agravante en la disposición de ciertos enterramientos y túmulos con escudo de armas por delante de las divisas reales. Sobre este asunto, el párroco Gonzalo Rodríguez Prieto exponía a Argüelles de Celles que las armas reales estaban grabadas en el púlpito, y que en lugar preferente a este habían dispuesto dos sepulcros que contenían los escudos de los Omaña. El regidor don José de Uría añadía que habían sido colocados con nocturnidad por don Lope, pues su padre ya lo había intentado, pero sin éxito, y que a pesar de no contar con el permiso del Rey ejecutó tal acción con la connivencia de su suegro, el capitán don Suero Queipo. Otros testigos, como el presbítero don Alonso de Llano Valdés incidían en esta última circunstancia y en el hecho de que don

26 BUO, Toreno, caja 33, doc. 13: Testamento de don Fernando de Valdés y Llano (Madrid, 27-V-1639).

27 Fernández Martín 1977: 298
Lope era «persona poderosa y emparentada con todos los caballeros y personas nobles de esta villa»; y Alonso de Uría precisaba que los sepulcros ornados con tales armas los habían usurpado a los descendientes de García de Valdés el Viejo, otra destacada familia del concejo, amparándose en la minoría del heredero. En sus conclusiones, el magistrado de Valladolid especificaba que los supuestos derechos en los que se amparaba Omaña eran los legados que había hecho su bisabuelo, Arias, a través de un codicilo de 1555, de 400 ducados a la iglesia para ornamentos y 600 más para un hospital en la villa a cambio de una sepultura en aquella parte, e incidía en la velada acción acaecida 28 años, según los testigos, "contra derecho y con muchas quexas» bajo el amparo de su preeminencia en la villa y la de su parentela. ${ }^{28}$ La impresión que se puede deducir de estos testimonios es la polarización de la vida socio-política del concejo alrededor de los Queipos, los Valdés y los Omaña, quienes abanderaban los bandos en la transición del medievo a la modernidad y cuyo empuje y acción, como clanes poderosos, derivó en la conformación de parcialidades, como ya he indicado. La inercia de estas circunstancias se observa entrado el siglo XVII y puede extrapolarse a otros ámbitos como la adquisición de lugares honoríficos en el templo.

Remitido el informe al fiscal del rey desde la Chancillería se valora la necesidad de mandar construir un nuevo templo y se daba un plazo de tres días a Omaña para retirar sus armas. A pesar de responder afirmativamente, don Lope no hizo nada, razón por la que fue acusado, junto a sus allegados, de rebeldía. El oficial regio solicitó una cédula en la que se instara al corregidor del Principado, a la sazón don Pedro Alarcón de Ocón, mandar quitar «de la capilla mayor de la iglesia de la Magdalena armas, tumbas y túmulos». ${ }^{29}$ En una sociedad basada en el honor, estos hechos vendrían a constituirse en afrenta, más aún cuando los Queipos reciban el patronato de la iglesia y en vez de reconstruir el vetusto edificio decidan la erección de un nuevo conjunto constructivo, que pusiera de relieve en el concejo su hegemonía.

La determinación de ceder el patronato a manos privadas no debió ser una decisión que necesitara ser muy meditada; la necesidad de restaurar y afrontar una serie de costes en una delicada coyuntura económica sería el justificante para que el prelado asturiano se hiciera cargo de los gastos tras la cesión del privilegio, que fue expedido el 6 de octubre de 1638 «con cargo y obligación de que aya de reparar la dicha iglesia y ponerla en forma que decentemente se puedan celebrar en ella los divinos oficios». Cuando el consistorio reconoció la merced consideraba que los nuevos patronos se encargarían de la restauración y ampliación del viejo templo en el que «las sepulturas que oy están se conserven en las personas que oy las tienen y en sus familias perpetuamente», y se mostraba entusiasmado pues el patronato no solo redundaría en el honor de los Queipo sino en el de la misma villa. En la toma de posesión, el representante del arzobispo solicitaba: "se le den los honores correspondientes, se le consienta hacer bóveda debajo del altar mayor para enterramiento de los patrones,

\footnotetext{
28 Ibídem: 289 y ss.

29 Ibídem: 298.
} 
hijos y sucesores». A partir de este momento otro sobrino del prelado entra en acción como representante y luego como testamentario: el jesuita Juan Queipo de Llano, al ser el coordinador de la nueva fábrica, que se llevó a cabo entre 1639 y 1642.

Poco antes de finalizar las obras irrumpe don Lope de Omaña como pleiteante, junto a otros regidores dependientes de su red clientelar: don José de Uría Valdés, don Francisco Flórez de Rojas y don Juan de Rojas Pambley. En la demanda se advierte que, ante la inminente consagración de la colegiata y la petición de traslado del sagrario y de la pila bautismal, se incurriría en la deshabilitación de la antigua parroquial, desprotegiéndose los enterramientos en ella contenidos, lo que interpretaban como un atentado hacia el espíritu del privilegio regio otorgado al arzobispo don Fernando, quien estaba obligado a la reconstrucción de la vieja parroquial, no a la erección de una nueva. ${ }^{30}$ El cruce de requerimientos, autos, peticiones y demandas entre las partes se multiplican a lo largo del mes de enero de 1642. Los demandantes llegan a poner en duda la necesidad de la nueva fábrica pues no tachan a la vieja de ruinosa, lo que contrasta con la información suscitada por los testigos unos años antes, algunos ahora partidarios de Omaña. El ejecutor de las mandas de los testamentarios de don Fernando intentó sortear los ataques derivando la documentación hacia éstos y su hermano, don Álvaro como patrón y heredero del arzobispo, responsables en última instancia. No obstante, el jesuita dejaba claro el tumulto provocado por don Lope pues «no es vecino de la villa por aver muchos años que está desavecindado de ella y no puede como tal vecino hacer pedimento alguno», además exponía que durante el tiempo en que duraron las obras, unos cuatro años, no había habido ninguna queja por parte de los ahora demandantes. El padre Juan Queipo estaba respaldado por el teniente de alcalde mayor y la mitad de la vecindad de la villa canguesa y observaba en la acción de Omaña y sus seguidores: «ynvidia y rencor que tienen y an mostrado siempre tener a la casa del dicho señor obispo, movidos más de esto que del agradecimiento que devían tener, sólo a efecto de que se pierda tan gran cantidad como en ella está gastada [30.000 ducados], a trueque de que no se quedase memoria en ella de la persona que tanto bien les hacía». ${ }^{31}$

Don Francisco Flórez de Rojas respondió a este alegato diciendo que los seguidores del jesuita no eran vecinos ni feligreses de Cangas, más bien criados del clérigo y de don Diego García de Tineo Llano, don Rodrigo y don Diego Queipo de Llano y Francisco Coque de Llano, quienes bajo la amenaza y la coacción les forzaron en el requerimiento. Aunque en todo momento, don Lope y consortes habían seguido la vía del tribunal eclesiástico, el primero, a título individual también exploró la civil, apelando al consejo de Castilla. Para que la causa adquiriera mayor peso incluyó el hecho de que en la antigua parroquial, según la tradición, reposaban los restos de uno de los hijos del «infante don Pelayo». A pesar de su discurso solicitaba en última instancia la desinhibición del Rey, pero no lo consiguió.

Desde el consejo se solicitaron los informes y conclusiones del entonces obispo don Antonio de Valdés y del

\footnotetext{
30 Ibídem: 299 y 301 y ss.

31 Ibídem: 314 y s.
}

alcalde de hijosdalgo, don Gutierre Argüelles de Celles, cuestión con la que no contaba don Lope y que no veía con buenos ojos al depender de las redes de los Valdés, en las que también estaban insertos los Queipo. ${ }^{32}$ No fue para menos, el obispo don Antonio sacaba a la luz una posible causa del conflicto: "le mueve [a don Lope de Omaña] el sentimiento que tiene de que Vuestra Magestad le hubiere mandado quitar unos entierros que tenía sobre las gradas del altar mayor pegado al altar al lado del Evangelio como si fuera patrón de la dicha iglesia, no teniendo derecho para ello». ${ }^{33}$ Tanto uno como otro recomendaban el traspaso de la custodia y de la pila bautismal al nuevo templo.

La causa se derivó a la justicia impartida desde el corregimiento de Asturias, vacante en el momento del pleito, teniendo que ejercer el teniente, don Jacinto de Escobar Porras, quien viajó a Cangas para hacer una comprobación visual de la situación. Allí hubo de oír a ambas partes. El partido omañista enfatizaba la vinculación del viejo templo con los orígenes de la monarquía asturiana. En este sentido, don José de Uría Valdés: "oyó decir que el infante don Pelayo o un hijo suyo estaba enterrado en esta iglesia; el sitio no lo sabe ni si es cierto, ni ay en la iglesia cosa ni señal que lo demuestre y la mayor razón es que se decía un cronista, no se aquerda de su nombre, lo avía scripto en su corónica». ${ }^{34} \mathrm{El}$ texto al que remite es la Historia pontifical y Cathólica (Salamanca, Casa de Gaspar de Portonarijs, 1577) ${ }^{35}$, del historiador Gonzalo de Illescas, quien a su vez alude al arzobispo de Toledo, Rodrigo Jiménez de Rada, y su De rebus in Hispania gestarum Chronicon. ${ }^{36}$ En el mismo bando estaba don Diego Flórez de Llano, quien vinculaba la posibilidad del regio enterramiento con el origen del patronato de la Corona: «el ser la iglesia antiquísima, su fundación de alguna persona real por cuya causa S. M. vino a tener el patronazgo de ella, donde están enterrados desde los primeros fundadores hasta hoy».

Por supuesto, la facción contraria no tenía constancia «que en la iglesia esté enterrado el infante Pelayo y ningún hijo suyo ni otra persona real» y enfatizaba el ofrecimiento del padre Juan Queipo para disponer en el nuevo templo nuevos y mejores lugares de enterramiento al resto de familias destacadas. El escribano Luis Méndez de Arbás

32 Sobre las redes forjadas por los Valdés en la administración central durante los siglos XVI y XVII, así como la inclusión en las mismas de los Queipo y los Argüelles vid. Fayard 1982: 233-236; Sobaler Seco 1987: 172-175; Sobaler Seco 2003: 461-476.

33 Fernández Martín 1977: 321.

34 Ibídem: 328.

35 Uno de los valores del Humanismo fue la recuperación de la Antigüedad clásica. Historiadores y eruditos del siglo XVı intentaron obtener un mayor conocimiento del cristianismo antiguo influidos por los acontecimientos reformista y contrarreformista que sufrió la Iglesia occidental a lo largo de la centuria; y orientaron el estudio de la arqueología cristiana hacia lo teológico y lo apologético, obviando o dejando de lado los estudios estilístico y formal de los restos conservados, al tener la falsa concepción que las primeras manifestaciones artísticas cristianas eran producto de un arte decadente alejado del brillo del periodo clásico. Será en este contexto en el que nazcan las primeras historias eclesiásticas y autores relevantes como Gonzalo de Illescas o fray Juan de Marieta; a la par aparecen los «inventores» de cronicones entre los que destacó Jerónimo Román de la Higuera; la finalidad no deja de ser una mera publicitación política y religiosa. [Corzo y García 2012: 218]. Sobre Illescas y su obra vid. Roldán Pérez 1974: 587-638.

36 Fernández Martín 1977: 318. 
especificaba que "los ricos viven en sus aldeas, donde tienen entierros y sepulturas con que se excusan de contribuir en los gastos y reparos de la iglesia dejándolos a los pobres». ${ }^{37}$

La puerta que había abierto don Lope y que intentó cerrar en el mismo momento, esto es, la vía civil y la intervención del consejo Real se continuó hasta el final; el hecho de que la parroquia hubiera pertenecido al patronato regio fue una causa de fuerza para explorar la situación antes y después de la cesión de los derechos al arzobispo don Fernando. El Consejo dictó sentencia en mayo de 1642 y falló a favor de la pretensión del jesuita de trasladar la custodia y pila de bautismo al nuevo templo, que fue consagrado por fray Diego de Herrera, abad del cercano monasterio de San Juan de Corias, el 4 de septiembre. Esta situación motivó que los Omaña, desairados, picaran de todas sus armas las de los Queipo a los que estaban unidos por lazos de consanguinidad, y realizaran la fundación de una suntuosa y amplia capilla funeraria en su solar de La Rozadiella (Tineo). ${ }^{38}$

\subsection{La dotación}

La fundación no fue baladí; dio lugar a un patronato privado importante en la comarca suroccidental del Principado, no solo en lo material y en lo espiritual, sino también en lo artístico. ${ }^{39}$ Supuso la construcción de un gran edificio, que sustituía a la antigua parroquial, y tenía unas obligaciones: misas, aniversarios, novenarios por el descanso del prelado y el de sus ascendientes y parientes a cargo de seis capellanes, uno de los cuales sería el receptor del curato y se distinguiría por ejercer de capellán mayor. Tenían la obligación de decir tres misas semanales cada uno. La sexta capellanía correspondía a un organista, con la tarea de una misa y media semanal y la ejecución del instrumento en los oficios cantados y otras solemnidades, así como la enseñanza del canto llano al resto de capellanes y a un coro de cuatro jóvenes. El desempeño de estas tareas tenía como sueldo 150 ducados anuales, a excepción del clérigo-músico que recibiría 200.40

Si bien la fundación data del mismo momento de la percepción del patronato, la presentación de estos beneficios no se inició hasta la finalización de las obras de la nueva iglesia y la disposición del mobiliario y menaje necesario para el rito eucarístico. Esta demora se alargó hasta el año 1656, si bien las primeras constituciones como texto estatutario sobre el que ha de regirse la fundación de las "memorias y obras pías del arzobispo" y a su clero, son de 1654. Este desfase temporal se debió a la necesidad de satisfacer aún deudas a los maestros de cantería y la

\footnotetext{
37 Ibídem: 329 y ss.

38 Ibídem: 341 y s.

39 Sobre esta última materia ha incidido el profesor Javier González Santos, no es mi propósito insistir en la misma. Para mayor información sobre las consecuencias artísticas de la promoción del arzobispo don Fernando de Llano y Valdés en el concejo de Cangas de Tineo vid. González Santos 1992 [2. - ed. corregida, aumentada y actualizada, 2009, 40 págs. (publicación en línea: http://www.touspatous.es/index.php/ biblioteca-digital/cat_view/81-biblioteca-digital/118-arte/117-gonzalez-santos-javier.html)]; González Santos 2014: 371-428.

40 BUO, Toreno, caja 69: doc. 1: Constituciones de las memorias que fundó don Fernando de Valdés y Llano (1654), s/f.
}

financiación del retablo ${ }^{41}$, un órgano, libros de canto y la construcción de un hospital y casa de estudios, también instituidos por el prelado.

Es probable que el fundador fuera consciente de los problemas que aquejaban al clero rural y feligreses, derivado de un sistema beneficial privado y arbitrario sobre individuos poco formados para dar servicio espiritual a las almas que de ellos dependían, desvinculándose de la provisión episcopal y dependientes de las redes tejidas por la nobleza. En todo caso es plausible que el primer texto constitucional fuera inspirado por el jesuita Juan Queipo. Estas disposiciones serían perfiladas en aspectos muy concretos en los años 1659 y 1666. En el primer documento los cambios afectan al número de misas que han de decir algunos de los capellanes y la satisfacción de ciertos pagos a costa de la casa de estudios. En el segundo se denuncia el no funcionamiento aún de la obra pía de estudios y hospital al agotarse los fondos de las rentas de los juros, que habían sido desviadas hacia algunos capellanes cargados con más misas; el cambio de varios juros por censos, al considerarse una inversión más segura; y la estipulación de un salario de 4.000 reales para el administrador del patronato. ${ }^{42}$

Para ser presentado a una de estas capellanías el patrón debía tener en cuenta una serie de criterios, el principal, la idoneidad del candidato, esto es, beneficiar a "personas áviles y suficientes». Esto implica varias cosas. En primer lugar se establece una edad mínima, fijada en veintitrés años, lo que no deja de sorprender pues el Concilio de Trento había estipulado los veinticinco como la edad mínima para la ordenación de presbíteros. Esta circunstancia ha de explicarse por cierta laxitud en la provisión de los beneficios de los patronatos privados, más sujetos al sistema de redes clientelares. ${ }^{43}$ De otra parte, hay una cierta dependencia de la mitra, pues tras ejercer el derecho de presentación los beneficiados debían ser examinados por el ordinario en "gramática, en teología, moral, en el reço, ceremonias de la misa y canto llano, y para poder administrar los sacramentos y el de la penitencia ${ }^{44}$; si superaban la prueba el obispo expedía el nombramiento, si no el patrón debía ejercer su derecho en otra persona. Esta medida, se debía a la calidad colativa de las capellanías, en la que no se excluía la intervención episcopal. El examen debía ser superado incluso por aquellos que ya hubieran sido consagrados presbíteros. No todos los eclesiásticos podían disfrutar del ejercicio de estas prebendas, eran incompatibles con el desempeño de otros beneficios dependientes de cabildos catedralicios y colegiales, o con el disfrute de un segundo curato, aunque dependiera del patronato de la casa condal.

Las constituciones estipulan la superioridad de la primera capellanía sobre el resto del clero colegial. Los presentados tenían obligación de residencia forzosa en la villa de Cangas; no podían abandonarla sin autorización, lo que estaba fuertemente penado, y será causa de algunas

41 BUO, Toreno, caja 73, docs. 35 (Ajuste entre el administrador y Pedro Sánchez de Agrela, Cangas, 17-11-1654), 36 y 37 (cartas de pago de Pedro Díaz Villabrilla, Cangas, 9-7-1657 y 6-6-1663).

42 BUO, Toreno, caja 69: docs. 2 (Traslado y auto de aprobación de las segundas constituciones, año 1659) y 3 (Terceras constituciones de las memorias y obras pías de Santa María Magdalena, año 1666).

43 Barrio Gozalo 2010b: 93 y s.

44 BUO, Toreno, caja 69: doc. 1: Constituciones (1654), s/f. 
discordias, como se verá en su momento. La reglamentación sobre la vida de estos capellanes es muy concienzuda al preverse la sustitución de aquellos que enfermaran o los que se ausentaran con permiso, pues se otorgaba un máximo de dos meses de libre circulación. Se llega al extremo de regular el uso de los hábitos.

A los seis capellanes hay que sumar la figura del sacristán, que no estaba contemplada por el arzobispo. El oficio era proveído por el párroco y estaba dotado de una renta muy menguada. En 1654 el conde don Álvaro decide suplir esta carencia, por lo que el titular del curato le cedió su derecho, a cambio de dotar la nueva plaza con una renta adecuada, fijada en cien ducados anuales y una carga de misa y media semanal, por lo que el beneficiado debía ser sacerdote. ${ }^{45}$

Pero, ¿cómo financiar esta promoción eclesiástica privada? Aunque no existe una biografía razonada del fundador en la que se observe su trayectoria política y su enriquecimiento como consecuencia del servicio a la Corona y la percepción de importantes rentas eclesiásticas, su patrimonio personal no debió ser despreciable. En sus últimas voluntades dota a la colegiata y su clero con diez juros que producían al año 1.442 .969 maravedíes (unos 3.858 ducados), consignados sobre los millones de diversas poblaciones del reino, salinas e impuestos del uno por ciento. ${ }^{46}$ Con ellos se costeó la erección del templo, su mobiliario y ajuar. El pleito suscitado por don Lope de Omaña informa que las obras, casi conclusas en 1642, superaban los 30.000 ducados, según estimación del maestro de obras y aparejador, Diego Ibáñez Pacheco. En la promoción arquitectónica no se escatimó. El arzobispo a través de su sobrino y provisor de la mitra metropolitana granadina, don Juan Queipo de Llano, obispo de Guadix, había encargado las trazas al arquitecto baezano y maestro de obras de La Alhambra, Bartolomé Fernández Lechuga. ${ }^{47}$

La dotación económica debía asegurarse a perpetuidad. Desde un punto de vista general, los instituyentes intentan buscar el medio de financiación más adecuado y seguro. Como tal se tenía la percepción de rentas fijas a través de los réditos de censos hipotecarios al quitar y de juros. El censo fue un instrumento crediticio en el que invirtieron los estamentos nobiliario y eclesiástico y fue utilizado como un medio más de aprovecharse de las malas condiciones económicas del campesinado, así como de los apremios de la administración local. Fue un negocio lucrativo pues el principal se colocaba a un interés que varió a lo largo del tiempo: del 7\% a finales del siglo xvı, pasó al 5\% en 1608. Lo atractivo de esta inversión estribaba en que el censualista no solo percibía unos intereses fijos en numerario, sino que a menudo a los censatarios, ante la imposibilidad de redimirlo, se les ejecutaba la propiedad hipotecada,

\footnotetext{
45 Ídem.

46 A estos bienes había que sumar seis juros con una renta global de 462.193 maravedíes (1.235 ducados) que costeaban otras obras pías: la escuela de primeras letras y de gramática, un hospital, la dotación de jóvenes doncellas pobres parientas del arzobispo y del concejo para casarse, y la institución de dos becas para realizar estudios universitarios. En todo caso, no fue hasta 1656 cuando esta pingüe renta (unos cinco mil ducados) comenzó a repercutir en los respectivos beneficiados.

47 Fernández Martín 1977: 335-337. Para el estudio históricoartístico de la colegiata remito a los trabajos del profesor Javier González Santos (vid. nota 39).
}

consignada siempre en bienes raíces, cuyo precio real era superior al del principal solicitado. ${ }^{48}$

También fue importante la inversión en deuda pública: juros. La percepción de su producto por parte de la nobleza perjudicó de forma indirecta a la administración municipal, dado que la Corona pagaba los intereses sobre las rentas reales locales. Su adquisición fue importante durante el siglo XVI, lo que se amplió hasta bien entrada la primera mitad del siguiente. Dejó de ser atractiva de forma paulatina por la disminución de su rentabilidad; en 1608 se reducía del 7,1 al $5 \%$ en los perpetuos, la medida no fue eficaz pues había muy pocos; en 1621 se estipula el $5 \%$ de interés en todos los juros "al quitar»; la reducción llegaría al 3\% en el segundo cuarto del siglo XVIII. La pérdida de interés de la nobleza por este producto tiene lugar cuando aumentan las retenciones y el impago de los réditos. ${ }^{49} \mathrm{~A}$ pesar de todo, estos productos no fueron despreciados, dado un cierto descenso de la rentabilidad de la tierra y del beneficio y seguridad de las grandes explotaciones, que animó a los inversores a diversificar sus ingresos. Juros y censos garantizaban la percepción de dinero líquido, que no dejaba de ser un «balón de oxígeno» para una aristocracia cada vez más endeudada y dependiente de unas rentas sobre la tierra que se cobraban en especie y que dependían tanto de la climatología como del mercado fluctuante del grano para su transformación en dinero.

El inicio de la disminución de la renta de los juros pronto se dejó sentir en la fundación, los retrasos en el cobro de los intereses supusieron un problema importante a partir del último cuarto del siglo XVII, poco después de ponerse en marcha la presentación de los primeros beneficiados. Contrario a la lógica, la casa de Toreno no tomó cartas en el asunto, hasta que fue demasiado tarde. En el primer cuarto del XVIII el conde don Fernando Ignacio hacía un extracto de los gastos derivados de las pensiones del clero colegial: capellanes, organista, sacristán, coro, fábrica del templo y otras cantidades menores, sumaban 950 ducados. El aristócrata elevó una consulta al canónigo magistral de la catedral de Oviedo, don Juan Fernández y Arango, en 1719 explicándole la reducción de la renta de los juros a la mitad «por la ynxuria de los tiempos se menos cavaron de tal suerte que lo que oy les a quedado será una quinta [parte]». El aristócrata había tomado la determinación de reducir los sueldos de los eclesiásticos a la mitad, y la duda que se le planteaba era si era lícito reducir también sus cargas, las misas a las que estaban obligados, a lo que el magistral responde afirmativamente: «no están obligados por razón del horden, como supongo, sino por razón del estipendio que reciben». Un agente del conde le había informado en 1712 sobre la disminución de la productividad de la deuda pública y la necesidad de tomar una decisión para compensar las cargas eclesiásticas con las pensiones. En otros casos, los fundadores, más que confiar en los juros lo hicieron en los censos desde un primer momento. En las escrituras se demandaba a los futuros patronos y administradores que si fueran redimidos se reinvirtiera el principal en el mismo

48 En la Asturias de transición de los siglos XVII al XVIII el grueso del capital invertido estaba en manos del clero, con el 64,5\% participativo, frente al $25,2 \%$ de la nobleza. Sobre este particular vid. Gómez Álvarez 1979: 13-19, 86 y 110; Gómez Álvarez 1993: 200.

49 Castillo Pintado 1963: 43-70; Toboso Sánchez 1987: 155-158; Carrasco Martínez 1997: 319-322; Domínguez Ortiz 2000: 789-806. 
tipo de instrumento crediticio para asegurar la renta de la fundación. ${ }^{50}$ Esta acción no siempre se constató, así se observa para el caso que estudio. Durante la segunda mitad del siglo XVIII, bajo el episcopado de González Pisador, los capellanes y el conde de Toreno habían llegado al acuerdo de poner en arriendo algunos bienes libres de la colegiata para complementar la renta de los capellanes. ${ }^{51}$

\section{LOS BENEFICIOS PARROQUIALES}

Si bien es cierto que la fundación de la colegiata imprimió a la casa de Toreno un importante reconocimiento y prestigio social, hasta el punto de hacer referencia a ella en los documentos importantes que emanaban de su secretaría, de tal modo que los condes, entre otros títulos, incluían el de "patrono in solidum de la iglesia colegiata y memorias pías que en la parroquial de Santa María Magdalena de dicha villa de Cangas fundó y donó el Ilmo. señor don Fernando de Valdés, arzobispo que fue de Granada y presidente de[I consejo de] Castilla ${ }^{52}$; lo cierto es que la familia ya había iniciado la forja de su patronato en el primer cuarto del siglo XVI de la mano de Suero el Viejo. Destacaron los beneficios curados de las parroquiales de San Juan Bautista de Vega de Rengos y de Santa María de Gédrez, así como el simple de la primera. La consolidación de estas preeminencias no estuvo exenta de conflictos y pleitos. Los orígenes de los problemas hay que verlos en las postrimerías de la Edad Media y el medio del que se sirvieron los Queipos para su obtención. La fuente económica que podía suponer la posesión de derechos beneficiales contribuyó en ocasiones a un sistema de compatronato. Esta situación podía afectar a dos o más familias por lo que la potestad de presentación resultaba de difícil determinación favoreciendo conflictos banderizos. ${ }^{53}$

Esta circunstancia se contempla en la parroquia de Vega de Rengos. Al menos desde el siglo xv los beneficios propios estaban compartidos entre los Collar y los Villar. El mayor de los conflictos lo supuso la presentación del curato. Para ejercer el derecho de un modo pacífico sendas familias decidieron contar con una tercera parte imparcial: el abad del monasterio de Corias, a la sazón don Pedro de Collar, miembro de uno de los linajes en desavenencias y que ejerció el abadengo del cenobio entre 1444 y 1474 . Según se desprende de un pleito posterior, el sucesor de este fraile aprovechó la situación para usurpar la presentación a sendas familias enemistadas "por ser el abad persona poderosa en aquella tierra» y recibir un yantar como derecho por ejercer la preeminencia. ${ }^{54}$ Este hecho será el origen de dos contenciosos entre los Queipos y, por un lado, el canónigo

50 Morgado García 1996: 37 y ss.

51 BUO, Toreno, cajas 69 [docs. 13: Consulta a don Juan Fernández Arango, magistral de la catedral de Oviedo y su respuesta (octubre de 1719); y 14: carta del licenciado don Andrés del Campillo y Cedrón al cuarto conde de Toreno (Oviedo, 13-1-1712)] y 70 [doc. 47: Informe de los capellanes y patrón de la colegiata de Cangas al obispo de Oviedo]. Díaz Álvarez 2003: 283-286.

52 BUO, Toreno, caja 30, doc. 26: Matrimonial entre don Joaquín José Queipo de Llano y Valdés y doña María Antonia Bernaldo de Quirós (Oviedo, 28-12-1754).

53 Catalán Martínez 2004: 148 y 159.

54 BUO, Toreno, caja 66, doc. 2: Pleito entre Juan Queipo de Llano y Valdés y el canónigo de la catedral de Oviedo, Juan Suárez de Taboada (1592-1594), ff. 90r y v; caja 67, doc. 5: Relación del pleito entre Juan de la catedral de Oviedo, Juan Suárez de Taboada, y, de otra parte, el monasterio de Corias. El conflicto se origina cuando Álvaro Collar de Villar y García de Villar, hacen donación de sus derechos en 1546 a Suero el Viejo. ${ }^{55}$ A pesar de ello los abades pretendían continuar percibiendo el yantar por la concordia entre los antiguos patronos, lo que motiva el contencioso. Aunque una primera sentencia falla a favor del monasterio, el pleito sería retomado por Juan el Mozo en 1576; las partes llegan a un compromiso en el que retornaba el derecho de presentación de los beneficios y el yantar a los Queipo a cambio de una compensación económica de 200 ducados. ${ }^{56}$

El pleito entre Juan el Mozo y el canónigo Juan Suárez de Taboada, mayordomo del obispo de Oviedo, tuvo lugar por el beneficio simple de Rengos en 1592, a raíz del fallecimiento del canónigo de la catedral de León, Diego de Quiñones; y se relaciona con el contencioso anterior cuando Juan el Mozo ejerce su derecho de presentación a favor de su pariente Juan de Llano de Valdés, inquisidor en el tribunal de Sevilla, y del clérigo Juan Álvarez de Barreiro. Cuando éste acudió al obispo para que tramitara su designación, lo hizo a favor del canónigo Taboada. Este hecho suscitó la reapertura del pleito por los derechos de la presentación vulnerados. El canónigo esgrimía que el simple de la parroquia era de presentación real y lo justificaba en el hecho de que los dos últimos beneficiados, Diego Díaz y Diego de Quiñones, habían recibido el título del nuncio apostólico y que el primero había sido presentado cuando su antecesor, Diego Arias, había renunciado en 1553 . Taboada apostillaba que era potestad del prelado proveer los beneficios simples aunque fueran de patronato de legos y no a su patrono, que Juan el Mozo no era el presentero ni nunca lo había sido, y que de haber tenido algún derecho fue por concesión del monasterio de Corias. También negaba la validez del compromiso que había alcanzado con su abad por haberse hecho sin el consentimiento papal y del ordinario de la diócesis, incurriendo, para más inri, en simonía por razón del pago que había ejercido. Juan el Mozo sale al paso de estas acusaciones reafirmando la titularidad del patronato y de sus derechos abalada por la escritura de donación que los Collar y los Villar habían hecho a favor de su abuelo Suero el Viejo en 1546; y que la falta del permiso del Papa o del ordinario quedaba compensado con la aprobación del General de la Orden de San Benito; asimismo, rechazaba la simonía justificando aquellos 200 ducados no como pago para la obtención del patronato sino como costas del proceso. Al final, se falla a favor de los Queipos en $1604 .^{57}$

El patronato sobre la parroquial de Gédrez se logró a

Queipo de Llano el Mozo y el canónigo Juan Suárez de Taboada, s/f, s/ fol; Floriano 1957: 291; Avilés 1991: 96.

55 BUO, Toreno, 67, doc. 10 Donación del patronato de los Collares y Villares a Suero Queipo (Posada de Rengos, 28-1-1546), inserta en Ejecutoria de concesión del patronato a los Queipos (1604), ff. 374v-379r.

56 BUO, Toreno, caja 67, docs. 4 [Compromiso entre Juan Queipo de Llano y el monasterio de San Juan de Corias (Corias, 12-1-1576)] y 5 (Relación del pleito entre Juan Queipo de Llano el Mozo y el canónigo Juan Suárez de Taboada, s/f, s/fol).

57 BUO, Toreno, cajas 66 [doc. 2: Pleito entre Juan Queipo de Llano el Mozo y el canónigo Juan Suárez de Taboada (1592-1594), ff. 105r y v.] y 67, docs. 5 (Relación del pleito entre Juan Queipo de Llano el Mozo y el canónigo Juan Suárez de Taboada, s/f, s/fol) y 10 [Ejecutoria de concesión del patronato de Vega de Rengos a la casa de Queipo (1604)]. 
través de la compraventa, pero a lo largo de un periodo de tiempo más dilatado, dado que estaba repartido entre varias personas. Los derechos sobre el curato recaían en un mayor número de individuos que en el caso anterior. Los problemas suscitados por la imposición de una facción podían ser más complicados, equivalentes a los patronatos ejercidos por el conjunto de una comunidad, habitual en los territorios del norte peninsular como ponen de relieve, desde una perspectiva general, Catalán Martínez y Barrio Gozalo. ${ }^{58}$ Como ejemplo de enrevesamiento al que podía llegarse pongo como ejemplo la provisión del curato y el simple de la parroquia de Santa Eulalia de Vigil (Siero), cuyo patronato era ejercido a partes iguales entre la casa de Vigil y los vecinos de la feligresía. Los problemas entre ambas partes desembocaron en diversos pleitos a lo largo de los siglos XVII y XVIII, llegándose a un acuerdo: los parroquianos ceden sus derechos sobre el simple a los marqueses de Santa Cruz de Marcenado y con respecto al curato permiten que el nombramiento fuera a cargo de los aristócratas a través de una terna emitida por los vecinos..$^{59}$ De otra parte, hay que tener en cuenta el hecho de que los porcentajes sobre los derechos ejercidos en Gédrez por una colectividad no están equilibrados. Para los Queipos, hacerse con este curato no fue sencillo, no tanto en lo conflictivo sino por el esfuerzo económico y de tiempo invertido de más de medio siglo. El proceso lo inició Suero el Viejo y su esposa María Alonso en 1519 al adquirir la parte que le correspondía a Álvaro Alonso; en 1537 repiten la operación con Pedro Fernández, quien les transfiere una serie de propiedades pertenecientes al patronato que ejercía en la parroquial. El sucesor, Juan el Viejo continuó con este proceso y en 1567 compra el octavo que ejercía Francisco García de Cangas, así como la parte correspondiente sobre los diezmos que percibía por sesenta ducados. Juan el Mozo adquirió la parte que le tocaba a Fernando Collar desembolsando veinticuatro ducados, y dos años más tarde permuta propiedades que rentaban tres cuartas de cereal por los derechos que ejercía Menendo de la Carril. De este modo, la casa de Toreno adquiriría la totalidad de la presentación del curato y la mitad de la percepción de la renta decimal. ${ }^{60}$ Este empeño supone una estrategia más para cimentar y consolidar su poder en el territorio, equiparable al observado en Vega de Rengos, parroquia en la que se hallaba uno de los solares de los Queipo: La Muriella.

En muchas ocasiones, la ausencia de títulos que probasen el derecho de presentación, así como el ejercicio a través de acciones paraseñoriales, dio lugar a procesos de detentación -que no ostentación- de los mismos. Esta pretensión por parte de la nobleza podía poner en el punto de mira derechos pertenecientes al patronato real. Así, el concejo de Valdés litigó con la casa de Navia desde finales del siglo xv por la presentación de los curatos de Santa Eulalia de Luarca y de Santiago de Arriba, a la que se acusó de usurpar el derecho a la Corona. El pleito se extendió en el tiempo hasta bien entrado el siglo XVII, fallándose a favor de los Navia e imponiendo pena de silencio a los vecinos,

58 Catalán Martínez 2000: 30 y ss.; Barrio Gozalo 2010a: 85 y s.; Barrio Gozalo 2010b: 23 y ss.

59 Díaz Álvarez 2003: 270 y s.

60 BUO, Toreno, caja 78: doc. 3: Presentación de Santa María de Gédrez. la obtención de las preeminencias fueron esgrimidas por la familia como mérito a la hora de remitir un memorial al Rey solicitando un título de Castilla. Un intento similar fue protagonizado por los Duque de Estrada en Llanes en la década de 1620 pero sin conseguirlo. ${ }^{61}$ No deja de ser un sistema similar equiparable a la apropiación de los cotos jurisdiccionales de la Iglesia, cedidos a miembros de la nobleza local durante la Edad Media para que ejercieran de comenderos; con el paso del tiempo se alzaron con su titularidad amparándose en el ejercicio del cargo desde generaciones. ${ }^{62}$

La obtención de un señorío suponía un ascenso social y un incremento del honor de la familia. La jurisdicción ejercida sobre los vasallos también se trasladó a lo eclesiástico pues en muchas ocasiones las parroquias insertas en los señoríos pasaron a estarlo del señor. La casa de los Queipos no fue ajena a este proceso, si bien accedió tardíamente a un señorío como titular del de Toreno, sito en la comarca leonesa de El Bierzo en 1638, no por concesión regia ni por compraventa entre particulares, sino como cesión en pago de una demanda que el conde don Álvaro interpuso a don Pedro de Merás. Éste fue sobrino y único heredero del capitán don Sancho de Merás († 1627), casado con doña Clara Queipo de Llano († 1630), tía de don Álvaro y de cuyo matrimonio no hubo descendencia. El capitán don Sancho fue acusado de abandonar a la esposa, lo que motivó su retorno al hogar paterno: los Queipo solicitaban a los Merás una compensación de diez mil ducados, entre otros motivos, como pago de la manutención de la desposada. Se falló a favor de los primeros. Entre las preeminencias del señorío se encontraba el derecho de presentación del curato de Santiago de Librán. No sería este el único coto del que disfrutaron los condes de Toreno. Por vía hereditaria percibieron el de Llanzol de Torrellas en Valencia, el de Tejedo en la montaña occidental leonesa, y el de Cerredo y Degaña en Asturias. ${ }^{63}$ En éste disfrutaban de la presentación de los curatos de Santa María de Cerredo y de Santiago de Degaña.

Estos derechos tuvieron repercusiones económicas positivas en los patrimonios de la Nobleza, que, a través del sistema beneficial privado, participó de los ingresos de la Iglesia con la percepción de rentas y diezmos. ${ }^{64}$ Este complemento económico constituía una fuente más de financiación de los patrimonios nobiliarios, del mismo modo que el aforamiento de tierras monásticas, que luego se subarrendaban obteniendo una importante rentabilidad. Esta práctica fue habitual entre la hidalguía asturiana. Un grupo concreto, la oligarquía urbana ovetense, compuesta por no pocas familias de la nobleza más destacada de la región, se sirvieron de estas acciones. No solo aforaron bienes de monasterios -al igual que se observa en Galicia-, sino también rentas eclesiásticas de diversas parroquias: los llamados «pies de altar» o diezmos de los curatos. Estos ingresos podían recibirse directamente o bien derivarse

61 Faya Díaz y Anes Fernández 2007: 333

62 Sobre la apropiación de antiguas jurisdicciones eclesiásticas vid. Tolivar Faes 1966; Faya Díaz 1992; Díaz Álvarez 2006b: 363-394.

63 González Ramírez 2007: 27-30; López Baamonde 2007: 83-86.

64 Catalán Martínez 2000: 30 y ss.; Barrio Gozalo 2010b: 21. 
hacia terceros como un medio de sustento. ${ }^{65}$ Según la profesora Faya Díaz la nobleza del occidente asturiano a mediados del siglo XVIII participaba del 14,8\% (unos 70.000 reales) de la renta decimal a través del patronato sobre beneficios eclesiásticos y capellanías, aunque fueron muy desiguales, tanto en lo que se refiere a los individuos como a su localización espacial. Entre los aristócratas asturianos con esta fuente de financiación destacaron los marqueses de Santa Cruz de Marcenado y de Ferrera. ${ }^{66}$

La casa de Toreno percibió rentas eclesiásticas procedentes del beneficio simple de Vega de Rengos, sus ingresos no debieron ser despreciables pues se agregaron al mismo vínculo. Los trámites para tal efecto los inició el segundo conde, quien en 1668 recibía respuesta de su agente en la Corte, informándole sobre sus pretensiones, ya logradas por otros aristócratas, si bien residentes en Italia, en Nápoles o en Roma al servicio de la Corona. En cualquier caso, le instó a que justificase su petición, dado que no se hallaba en suelo italiano, y que obtuviera un consentimiento del obispo, recomendándole que expusiera el mal estado de las parroquiales que pretendía y la necesidad de costear las reparaciones y ornamentos que precisaban. También le advierte que no sería difícil obtener la gracia que solicitaba al Sumo Pontífice Clemente IX por la estima que le había tenido a su padre. ${ }^{67}$ Así actuó el conde, que no solo aspiraba a los diezmos y rentas de aquella parroquia sino también a los de su señorío de Toreno, en el que únicamente disfrutaba del derecho de presentación durante un tercio del año. Los motivos esgrimidos se resumen en la pobreza y poca renta que ofrecía la casa condal, evaluados en tres mil ducados; la donación de una serie de rentas a la fábrica y feligresía, así como de 150 ducados por un nuevo retablo y otros ornamentos. Glosaba como mérito la fundación de las obras pías que había hecho su tío abuelo, el arzobispopresidente, así como ser sobrino nieto de los notables teólogos, jesuitas y hermanos cardenal don Juan de Lugo y Quiroga (Madrid, 1583-Roma, 1660) y don Francisco de Lugo (Madrid, 1580-Valladolid, 1652); y concluye con un memorial de los servicios de su padre, el conde don Álvaro y de los cuantiosos gastos que le supusieron sus servicios al Rey. Las gestiones del aristócrata fueron exitosas pues en 1672 el beneficiado simple, el bachiller Jerónimo Valcarce, comisario del Santo Oficio y cura de San Juliano de Arbás, hacía donación de los diezmos que disfrutaba al conde (un tercio de los mismos, los dos restantes los percibía la mesa del cabildo catedralicio). ${ }^{68}$ Avanzada la cronología, estas rentas podían cobrarse directamente o arrendarse a terceros por una cantidad fija. Así procede el conde don Joaquín José en un contrato de cuatro años sobre los frutos menores

65 Catalán Martínez 2004: 143 y s. y 160; Díaz Álvarez 2008: 230 y ss. y 278 y s.

66 Faya Díaz y Anes Fernández 2007: 332.

67 BUO, Toreno, caja 68: Carta de Isidro Jacinto de Paul al segundo conde de Toreno (Madrid, 18-12-1668). La amistad del primer conde con el papa Rospigliosi pudo haberse fraguado cuando el italiano, aún obispo, pasó a Madrid como Nuncio Apostólico de la Santa Sede (16441652); en esa época don Álvaro ejercía el corregimiento de la Villa y Corte. Sobre el gobierno del aristócrata asturiano puede consultarse Hernández 1991: 579-606.

68 BUO, Toreno, caja 68: Motivos alegados por el conde de Toreno para pretender la percepción de ciertos diezmos (1669); Donación de los diezmos de Vega de Rengos al conde de Toreno (8-3-1672). (patata, lino, lana, hierba, naciones, manteca y nabos) de la parroquia de Gédrez en 1801 a favor del párroco de la feligresía: Francisco Díaz Guelpe, por 40 ducados anuales; el resto del diezmo lo percibía directamente el aristócrata. ${ }^{69}$

\section{CAPILLAS Y CAPELLANÍAS}

Dentro de la hidalguía notoria del Principado, al igual que la del resto del reino, la gestación del patronato de legos estaba sustentada más en la promoción de capellanías, que en la obtención o la apropiación de beneficios eclesiásticos. Su disposición fue más asequible y tenía el atractivo de encubrir la creación de pequeños vínculos gestionados desde el seno de la familia y con libre potestad para presentar a los clérigos que debían de hacerse cargo de las mandas espirituales. Tras esta realidad subyacía un principio de la responsabilidad colectiva y solidaria de la familia hacia aquellos hijos excluidos de la herencia del vínculo. ${ }^{70}$ La disposición de una capellanía tenía un fuerte componente económico, pues no dejaba de representar una masa de bienes vinculados a un fin religioso con una carga específica de misas sobre un altar determinado en una capilla o de una iglesia parroquial o conventual, ${ }^{71}$ de tal modo que la construcción de una ermita, acondicionándola con mobiliario y ajuar y proveyéndola de una dotación que sirviera para el pago de los servicios de un clérigo, no era tan importante, sí más costoso. La promoción de estas iniciativas suponía un esfuerzo crematístico para unas construcciones religiosas privadas -en ocasiones con funciones funerariasvinculadas, o no, a las residencias aristocráticas, tanto en el ámbito urbano como en el rural. ${ }^{72}$ Un ejemplo de la importancia numérica y económica de las capellanías se observa en la diócesis gaditana a lo largo del siglo XVIII, pues el monto total de las dotaciones superaba los doce millones de reales. ${ }^{73}$

Este comportamiento no fue ajeno a los Queipos, que disponían de una capilla bajo la advocación de San Bartolomé, en el lado del Evangelio del recoleto y vetusto templo parroquial de Cangas. Este recito fue utilizado como lugar de enterramiento familiar desde su fundación por de Juan Queipo de Cangas, en una fecha indeterminada que presumiblemente hay que situar en la transición de los siglos XV al XVI, hasta la construcción de la nueva iglesia colegial. Sus trazas eran sencillas, sección oblonga y cabecera semicircular, como la del altar mayor. Suero el Viejo al testar en 1549 deja constancia de ello: «que por quanto [...] mi padre fundó la capilla de San Bartholomé e dejó ciertas misas que en ella se dijesen cada semana e para ello dejó quatro eminas de pan de renta [...], según de su testamento consta [...]». Esta dotación había sido aumentada en tres eminas por Luis Queipo, hermano de Suero, al testar y fallecer en 1525, imponiendo como carga un aniversario anual. Será aquél quien reconvierta la dotación a veinte eminas de cereal y

69 BUO, Toreno, caja 78, doc. 1: Arriendo de los frutos menores de Gédrez (Cangas, 22-8-1801).

70 Domínguez Ortiz 1973: 252; Ramos Cobano 2011: 412.

71 Diversas hipótesis al respecto pueden consultarse en González Ruiz 1950: 475-501; Fernández Cubeiro 1981: 205-215.

72 A este respecto vid. Ramallo Asensio 1998: 359-372.

73 Morgado García 1996: 37 y ss. 
la renta sobre una casa en Cangas y una viña en Arceliz, al ser insuficiente para cubrir la carga de dos misas semanales que había instituido su padre más las que él mismo fundó: dos misas y un aniversario perpetuo de una misa cantada con vísperas y cinco rezadas el día de Nuestra Señora de Adviento. Tres nuevos legados incrementarían la capilla. Uno se debe a Juan el Mozo, quien graba con otro aniversario de una misa cada sábado y otra en las festividades de Nuestra Señora a cuenta del quinto que percibiría el heredero del mayorazgo; el segundo al capitán don Suero, quien al fallecer en 1633 carga un nuevo aniversario de seis misas con sus respectivos responsos. La tercera manda la instituye el arzobispo don Fernando de Valdés Llano en 1639: seis aniversarios a cuenta de la dotación de los capellanes de la colegiata. ${ }^{74}$ Junto a esta capilla hay que tener en cuenta la ermita de La Muriella aneja al solar que los Queipos tenían en Vega de Rengos. La construcción data de finales del siglo XVI cuando la funda Juan el Mozo en 1584 dotándola con una renta anual de quince eminas de pan. El segundo conde amplía la promoción con la donación de una serie de ornamentos litúrgicos, además de un cáliz y una patena de plata en $1666 .^{75}$

El patronato fundado por el arzobispo fue lo suficientemente amplio e importante como para que los herederos del mismo no se preocuparan de aumentarlo con otras disposiciones; no obstante, hubo algunas nuevas promociones. El conde don Fernando, si bien absentista del Principado, funda una nueva capellanía en la iglesia colegial de Cangas. La instituyó bajo la advocación de Nuestra Señora del Rosario, tenía la carga de un rosario diario en el templo cangués, a cuenta de uno de los capellanes, y la dotó con 505 reales anuales consignados en un censo contra la villa de Esquivias de 6.700 ducados de plata de principal. El clérigo percibiría por su labor 30 ducados, 100 reales se repartirían entre los mozos del coro y 59 los embolsaría el administrador. La escritura fundacional, emitida en Madrid en 1678 , estipulaba que si la renta disminuyera por efecto de la variación de los intereses de juros y censos, se debía reducir la carga, pero el tercer conde la mantendrá fija al proveerla de la financiación necesaria. La despreocupación del cuarto conde por no reinvertir los censos redimidos le obligará a financiar la diferencia del coste de la renta dispuesta. ${ }^{76}$

La capellanía de San Nicolás de Bari y Santa Polonia fue fundada por los terceros condes el 14 de julio de 1697, en uno de los altares de la parroquial de Vega de Rengos. El espíritu de la fundación fue dar cobertura espiritual a los viajeros que transitaban por el camino real hacia Castilla, sobre todo a aquellos que se dedicaban a la arriería, por la lejanía con respecto a otros templos. La carga era una

74 BUO, Toreno, caja 33, docs. 3 [Testamento de Suero Queipo de Llano (Cangas, 27-X-1549)], 5 [Testamento de Luis Queipo (Cangas, 10-81525)], 8 [Testamento de Juan Queipo de Llano el Mozo (Cangas, 29-71594)], 12 [Testamento del capitán don Suero Queipo de Llano (Cangas, 23-2-1633)] y 13 [Testamento del arzobispo don Fernando de Valdés y Llano (Madrid, 27-5-1639)]. La imagen de la capilla de San Bartolomé puede observarse en González Santos 2014: lámina XIII.

75 BUO, Toreno, caja 65, doc. 2: Inventario de papeles sobre el derecho de presentación de los beneficios propios de Vega de Rengos (vid. docs. inventariados con los números 33 y 34).

76 BUO, Toreno, caja 76: doc. 1: Libro de pago de misas en Cangas de Tineo. misa dominical y otra cada día festivo al amanecer; de ahí su denominación, más que por su advocación, se la conoció como «la misa del Alba». En 1704 los promotores aumentan las obligaciones en 22 misas. La dotación inicial fue un juro que rentaba 48.071 maravedíes anuales y tres censos de 170 ducados de principal que producían unos intereses de 8,5; la dote fue incrementada con cinco censos más que sumaban 410 ducados de principal y surtían 225 reales y 18 maravedíes y varios bienes raíces que rentaban dos eminas de cereal, un carnero, una marrana, un cabrito y dos gallinas. Los capellanes no recibían todos estos productos por su labor pastoral, sino 43 ducados, aumentados a 18 más en 1704; el resto debía quedar como remanente para abonar los gastos ordinarios y el administrador pasaba a percibir un $16 \%$ de la renta total. Al igual que con la dotación de la colegiata, la disminución de los tipos de interés de juros y de censos pasa factura. El empecinamiento de los fundadores en mantener las misas aunque disminuyeran las rentas acarreará consecuencias al sucesor. En 1740 don Fernando Ignacio hace consulta para ajustar la descompensación entre el producto de la dote y las cargas. A diferencia de lo que había hecho en Cangas, aquí intenta poner remedio aumentando el principal del juro y el número de censos. ${ }^{77}$

La casa de Toreno fue receptora de otras fundaciones tanto en Asturias como en otros puntos de la Península. Las cito aquí con brevedad por la íntima relación de sus beneficiados con del patronato eclesiástico asturiano: el clero de la colegiata de Cangas y curatos más representativos. A través del mayorazgo de Lugo, incorporado a la casa de los Queipo por la muerte sin descendencia de doña María Josefa de Chaves y Lugo, condesa de Molina, en 1679, sobrina de doña Ana Mauricia y prima del segundo conde de Toreno al que instituye como heredero, se incorporan dos capellanías en la ciudad de Sevilla. Una sobre uno de los altares de la iglesia conventual de San Leandro, fundada por doña Ana María de Carrasco, religiosa que había profesado de ese cenobio; la otra recaía en un altar de la parroquial de San Bartolomé y había sido fundada por el capitán don Pedro de Ybarra, como testamentario de su esposa doña María de Mendoza, abuelos maternos de doña Ana Mauricia. ${ }^{78}$

El tercer conde recibe en herencia de su madre doña Josefa Jiménez de Arellano el vínculo de la casa de Arnedo, solar localizado en la localidad riojana de la misma denominación. A él estaba vinculado el patronato de la capilla de San Juan en la iglesia parroquial de Santo Tomás de aquella villa y la capellanía de San Cosme y San Damián. ${ }^{79}$ El aristócrata también recibe la herencia de su tía, la condesa viuda de Montalvo, doña Isabel María de Zúñiga y Queipo († Madrid, 1699). Aunque receptora del vínculo de su madre, en el que se incluía el señorío conquense de Valparaiso de Abajo, no se lo deja a su sobrino, sino al que

77 BUO, Toreno, caja 74, docs. 1 [Libro de cuentas de la capellanía de la misa del Alba (contiene la escritura fundacional, dada en Cangas, a 14-7-1697)] y 10 [Consulta sobre la fundación de la misa del Alba (año 1740)].

78 BUO, Toreno, caja 72, doc. 13: Libro registro de nombramiento de oficios y presentaciones.

79 BUO, Toreno, cajas 24 [doc. 14: Matrimonial de don Fernando Queipo de Llano y Valdés con doña Josefa Jiménez de Arellano (Madrid, 23-8-1658)] y 33 [doc. 16: Testamento del licenciado don Atanasio Jiménez de Arellano, caballero de Calatrava, fiscal del consejo de Órdenes (Madrid, 1657)]. 
correspondiera en la línea sucesora materna; en cambio sí le traspasó el que poseía en Valencia: Llanzol de Torrella, que había heredado de su primer marido, el conde don Antonio Ordoñez de Castro. En cualquier caso, entre las fundaciones religiosas y pías que dispuso la dama madrileña están dos capellanías. Una en la capilla funeraria del Santísimo Cristo del Consuelo, sita en el convento madrileño del Espíritu Santo de Clérigos Menores, lugar donde mandó enterrarse y de la que era patrona, privilegio que traspasó a su pariente. La capellanía la dotó con los réditos de un censo contra la villa de Madrid sobre la sisa de la carne de 60.000 reales de principal, y disponía que debiera hacerse el nombramiento de capellán en uno de los clérigos del cenobio. La segunda capellanía la realizaba en el hospital madrileño de la Buena Dicha, dotada con la renta de un solar en la calle Silva. ${ }^{80}$

En 1706 el tercer conde también era receptor de la herencia de doña Felipa Zapata de Mármol, viuda del santiaguista y consejero en el de Órdenes Militares don Fernando Queipo de Llano, miembro de una rama segundona de la casa de Toreno, dado que su descendencia se había malogrado. Entre las propiedades se encontraba una capellanía que había fundado en la colegiata canguesa años atrás, con una carga de tres misas semanales y una dotación de 150 ducados anuales sobre la renta de una escribanía real en la Cámara de Castilla, que se integró en el vínculo de los Queipo. Aunque a doña Felipa se le debe la fundación por manda testamentaria en 1689, se la había encomendado a su sobrina doña María de Garco Porcel y Cobos, viuda de don Manuel Queipo de Llano y Valdés. A su óbito no había cumplido con su obligación, que transfiere por vía testamentaria en 1705 a su heredero: el conde don Fernando. Éste se desinhibe de la tarea a favor de su hijo y sucesor, don Fernando Ignacio, que sería el que la materializaría en 1736 casi medio siglo más tarde de la intención de Zapata. ${ }^{81}$

\section{PRESENTACIÓN DE BENEFICIADOS Y CONFLICTIVIDAD}

Resulta evidente observar que este patronato tiene una clara estructura jerárquica, del mismo modo que se puede observar en el ejercido por la Corona. ${ }^{82} \mathrm{El}$ ámbito más prestigioso será la presentación del clero de la colegiata de Santa María Magdalena de Cangas del Narcea, le siguen los curatos de San Juan de Vega de Rengos con su hijuela de Santa Eulalia de Larón, y de Santa María de Gédrez, así como los de los cotos de Toreno y Cerredo: Santiago de Librán, Santa María de Cerredo y Santiago de Degaña. Hay una clara diferencia entre los beneficios propios de parroquias realengas de los que estaban en espacio de señorío. En último lugar estaría la presentación de las capellanías fundadas y heredadas en Asturias, Madrid, Sevilla y La Rioja. A la capellanía mayor de Cangas se llegaba por haber ejercido antes uno de los curatos. Incluso entre éstos solía haber un sistema de promoción en los que primaban los localizados en espacios de realengo sobre los de señorío.

80 AHN, Sec. Nobleza, Toreno, C.32, D.129 (Testimonio de la cesión de los bienes en Llanzón de Torrella, que incluye copia del testamento y codicilo de doña Isabel María de Zúñiga y Queipo, año 1802).

81 BUO, Toreno, cajas 76 (doc. 1: Libro de pago de misas en Cangas de Tineo) y 78 (doc. s/n: Fundación de doña Felipe Zapata de Mármol).

82 Barrio Gozalo 2010a: 177.
Esta organización se adivina por el ascenso de algunos clérigos dentro del sistema beneficial condal, pero no fue lo habitual; del mismo modo que se advierten algunas carreras singulares. Las fuentes utilizadas son parciales, no arrojan luz sobre la totalidad de los individuos presentados a todas las congruas; se refieren a 60 individuos entre 1655 y 1803. Incidiré en algunos.

José Antonio Díaz Fernández llegó al curato de Cangas en 1728 , tras haber servido durante tres años el de Vega de Rengos, hasta su muerte en 1761; Jerónimo Faya fue presentado al de Librán, y pasó en 1784 a la capellanía mayor canguesa. En ocasiones la llegada a la colegiata no era para desempeñar este beneficio sino una de sus otras cinco capellanías, así le sucedió a Nicolás de Sabugo y Valcarce, que en 1704 fue presentado capellán en Cangas, donde falleció en 1718, tras haber ejercicio el sacerdocio en Santa María de Castañedo (Cangas del Narcea). Lo mismo le sucedió a Rodrigo de Mon, en 1685 deja el mismo curato para acceder a una de las gruesas capellanías hasta su muerte hacia 1699. Los licenciados Francisco Fernández de Llano y Juan García del Valle Rosal desarrollan carreras semejantes, ambos fueron presentados a una de las capellanías de la colegiata, pasando luego a ejercer el curato de Gédrez, el primero entre 1686 y 1703 y el segundo entre 1703 y 1711. Antonio Martínez de Llano pasó por varios curatos de las jurisdicciones de los Toreno, primero en Cerredo (17831785), luego en Librán (1785-1803), hasta terminar en la parroquial berciana de la Purificación de Villamartín del Sil, cercana a la jurisdicción de Toreno. ${ }^{83}$

Hay casos en los que los beneficiados procedían de otros patronatos de legos o prefieren cambiarse a ellos o incluso a sedes dependientes de la presentación real, lo que se hacía efectivo a través del obispado de la diócesis. José Agustín López de Carracedo había sido canónigo de la colegiata de Pravia, perteneciente a la casa de Arango, donde ejerció hasta 1783, año en el que accedió al curato de San Juan de Vega de Rengos, y en el que se mantuvo hasta su fallecimiento en 1798 . Un caso inverso lo vemos en una fecha avanzada; el 4 de mayo de 1829 vacaba el curato de Gédrez, en el que había sido presentado José Frade de Sierra, por su promoción al de San Pedro de Gijón. ${ }^{84}$

Estos ejemplos ponen de manifiesto la movilidad del bajo clero incluso dentro del entramado del patronato eclesiástico privado. En el caso que atañe no fue la tónica general. Como indiqué más arriba la muestra corresponde a 60 eclesiásticos, de los que solo 18 (apenas un tercio) logran un mayor recorrido en sus carreras profesionales. Lo habitual fue que los beneficiados se mantuvieran inamovibles en sus correspondientes sedes hasta su óbito. Esto es más evidente entre aquéllos que fueron proveídos con la plaza de capellánorganista de la colegiata de Cangas. Su labor era importante dadas sus funciones: además de las cargas pastorales a las que estaban obligados, eran los encargados de ejecutar la música en la liturgia y la enseñanza del canto llano, en tanto que maestros de capilla. Las fuentes son lacónicas respecto a estos clérigos-músicos; no indican de dónde procedían,

83 BUO, Toreno, caja 72 docs. 13, 16 y 17 (Libros registro de presentaciones de beneficios y capellanías).

84 BUO, Toreno, cajas 72 (doc. 17: Libro registro de presentaciones de beneficios y capellanías) y 78 (doc. 3: Recepción de cartas solicitando la vacante del curato de Gédrez). 
ni dónde se formaron. Cabe señalar la excepción de Gil Muñiz que recala en Cangas hacia 1704 procedente de la capilla musical de la catedral de Oviedo para ocupar «la plaza de organista»; no obstante, estaría poco tiempo en su destino, unos siete años, al regresar a la sede ovetense como cantor. ${ }^{85}$ También ejercieron sucesivamente el puesto: Gaspar de los Reyes, hasta su muerte en 1698; Antonio de Ron, del que se desconoce la fecha de su magisterio; Diego García de Cosío, que ejerció hasta 1720 en que causa baja por ausentarse sin especificarse los motivos y su sustitución por su hermano, Juan Antonio Cosío. A este le sucede Juan Rodrigo Alonso hasta el año 1780 en que solicita al conde don Joaquín José su jubilación por su avanzada edad y achaques, que le impiden acudir a sus obligaciones, y su sustitución por un interino, plaza proveída en Manuel González Ruidíez. ${ }^{86}$ La importancia de estos profesionales, pues no solo se ejercitan en la música durante la liturgia sino que tienen una función docente, queda atestiguada por el hecho de que un porcentaje significativo de los músicos de la catedral de Oviedo procedían de Cangas del Narcea. La colegiata podía ser un foco de formación destacado, así como el vecino monasterio de Corias. ${ }^{87}$

En ocasiones, la promoción no era bien acogida y el clérigo meditaba los pros y los contras de un cambio. En 1798 vacó la parroquial de Gédrez y don Joaquín José se vio en la necesidad a hacer nueva presentación, para ello emitió al ordinario dos nombres, Francisco Rubio, cura de Cerredo, como primera opción y Francisco Díaz Guelpe, como segunda. El patrón había escrito a Rubio el 27 de abril comunicándole su decisión y la necesidad de pasar los trámites requeridos en el obispado. En la decisión del aristócrata debió interceder el tío del propuesto, párroco de Vega de Rengos. El conde se impacientó al no recibir la aceptación, a pesar del movimiento de las redes, como lo expresa en la carta que le remite el 7 de mayo: "No puedo dejar extrañar y habiendo remitido a V. M. el día 27 del pasado el título del curato de Gédred, por su tío el cura de Vega, en vista de haberlo aceptado V. M. cuando se lo propuse en La Muriella, no me haia abisado hasta ahora [...]».88 El patrón tenía la necesidad de disponer del curato de Cerredo que quedaría vacante para reorganizar los beneficios. El clérigo meditabundo dio respuesta tres días más tarde rechazando la gracia condal. En su decisión pesaba el mal estado de la casa rectoral a la que debía trasladarse y la inversión que había hecho de 4.000 reales en la de Cerredo por el mismo objeto, lo que se vería obligado a repetir. ${ }^{89}$

Los casos de Francisco Rubio y de Juan Antonio Cosío ponen de relevancia otra cuestión: el modo de acceso a la carrera eclesiástica, privada o dependiente del patronato regio -también a las que se inician en la administración de la Iglesia-, que en muchos casos se deben a un pariente

\section{Quintanal 1983: 41.}

86 BUO, Toreno, caja 72, doc. 16: Libros registro de presentaciones de beneficios y capellanías.

87 Quintanal 1983: 183 y s.

88 BUO, Toreno, caja 72, doc. 16: Libro de presentaciones de beneficios (incluye carta del conde don Joaquín José a Francisco Rubio, Cangas, 7-5-1798).

89 Idem, (incluye cartas de Francisco Rubio al conde don Joaquín José, Cerredo, 10-5-1798). ya clérigo. ${ }^{90}$ Un ejemplo más se ve en el ya citado alcalde de Hijosdalgo de Valladolid don Gutierre, que desarrolló una importante carrera al servicio de la Iglesia y la administración central desde la que alentó la de su sobrino, don Pedro Argüelles de Celles, que aun siendo el heredero del mayorazgo de su casa fue dirigido a la vida clerical en la que llegó a ocupar el deanato del cabildo catedralicio de Santiago de Compostela. ${ }^{91}$

Las constituciones de la colegiata canguesa insisten en la incompatibilidad del disfrute de dos beneficios propios. Con ello se intenta asegurar una dedicación exclusiva, evitando la acumulación: el exceso de cargas repercutirían en los feligreses por quedar desatendida su cura de almas, y redundaría en el nombramiento de "excusadores", a los que había que pagar. Pero no siempre fue así; hubo excepciones. Tomás González de Valcarce y Rodrigo de Mon lograron dispensa, el primero era cura párroco de Robles, el segundo capellán en Cangas, sendos religiosos recibieron el beneficio simple de Rengos, sucesivamente y respectivamente en 1697 y en $1699 .{ }^{92}$

Empero, sí queda reflejada la compatibilidad de uno de los beneficios curados con el ejercicio de una o más del resto de capellanías fundadas o heredadas por los Toreno. Me refiero a las del Rosario, la misa del Alba y la fundada por doña Felipa Zapata, las de San Leandro y San Bartolomé en Sevilla o la del Cristo del Consuelo en Madrid. A excepción de ésta, que se proveyó en frailes de la congregación del Espíritu Santo de Clérigos Menores, el resto se hizo sobre clero asturiano, que no tuvo la necesidad de residir en sus lugares de asiento: percibían la renta y tenían potestad para nombrar sustitutos. Aunque para el caso que atañe no hay documentación explícita el sistema de creación de excusadores, incluso coadjutores, no deja de suponer un medio de acceso a la Iglesia, la formación de redes clientelares y sagas familiares, como he observado. ${ }^{93}$

En líneas generales, estas capellanías no dejarán de ser un complemento económico para este clero, sobre todo para el de la colegiata, dado que su congrua comenzará a disminuir por el efecto de la reducción de los réditos de los juros a partir del último cuarto del siglo xVII, y de un modo más drástico en la década de 1720 . Esta tendencia se inaugura a finales del siglo XVII, tras el retorno de los condes de Toreno de su absentismo a su solar de origen, $y$ parece que se rompe en los albores del siglo XIX, cuando es presentado a las capellanías sevillanas Francisco de Paula Cabrera, cura-secretario del hospital del Espíritu Santo. Entre el clero asturiano, uno de los que más rentas acumuló fue Rodrigo de Mon, capellán en Cangas desde 1685, al final de su carrera fue presentado a las capellanías del Rosario y a las sevillanas. Otros capellanes beneficiados fueron Francisco Fernández de Llano y el organista Antonio de Ron, en 1683 y 1699, respectivamente, con la del Rosario; o Lorenzo Fernández de Is y Bernardo García del Valle Valdés, y el cura de Vega de Rengos José Antonio Díaz Fernández con la de San Leandro en 1708, 1722 y 1761.

\footnotetext{
90 Barrio Gozalo 2010b: 76 y s.

91 Díaz Álvarez 2009: 513.

92 BUO, Toreno, caja 72, doc. 13: Libro registro de presentaciones de beneficios y capellanías.

93 Morgado García 1990: 357; Barrio Gozalo 2010a: 61 y s.; Barrio Gozalo 2010b: 223 y ss.
} 
Otros personajes dependientes de la clientela de la casa condal, o bien seglares, o bien con órdenes menores, absentistas o no, fueron agraciados con algunas de estas rentas y autorizados a nombrar excusadores que se hicieran cargo de las obligaciones eclesiásticas. La capellanía de Zapata fue presentada en primer lugar en don José Flórez de Valcarce, estudiante de leyes en la universidad de Salamanca; su renta no dejaría de ser un complemento económico de la beca que disfrutaba, también del patrocinio de los Toreno. Algunos segundones de los condes fueron beneficiados, con la finalidad de darles una renta que les permitiera el sustento al amparo de la casa y bajo la protección del mayorazgo. El simple de Vega de Rengos fue disfrutado dentro de la familia desde el siglo XVII. En 1735 don Fernando Ignacio presentó a su hermano menor don Ignacio Jesús, quien también disfrutó de la capellanía de doña Felipa desde 1748 hasta su muerte en 1791. En estos dos beneficios sucedieron sus sobrinos don Fernando Máximo y don Antonio María Queipo de Llano, hijos del conde don Joaquín José.

De otra parte, el hecho de que el patrón ejerciera su derecho de presentación en terceros, no significa que la relación entre ellos fuera pacífica. Los problemas entre ambas caras de la misma moneda no fueron extraños. En 1740 el capellán de la colegiata y de la capellanía de la misa del Alba, Francisco Collar, interpuso pleito a don Fernando Ignacio al considerar sus cargas pastorales excesivas frente a la renta percibida, pues se había reducido por la caída de los intereses de los juros y la redención de censos no vueltos a invertir. Aunque el ordinario falló a favor del aristócrata, Collar mantuvo una acción de rebeldía al reducir de modo unilateral las misas a las que estaba obligado. El caso fue llevado a la nunciatura, que volvió a fallar a favor del conde en 1752, condenó al clérigo al pago de 20 ducados, decir las misas que omitió entre septiembre de 1751 y febrero del año siguiente y apercibido «de que en adelante cumpliese exactamente y no se propagase a hablar mal, por escrito ni de palabra, con persona alguna y especialmente con el conde ${ }^{94}$, por lo que se ha de suponer que dio lugar a habladurías en la recoleta villa canguesa.

Uno de los principales conflictos tuvo lugar unos años antes, en 1724, y afectó no solo a la relación entre el conde y el clero de la colegiata, sino que también intervino el ordinario eclesiástico desde Oviedo y el titular de la mitra. La causa la generó el capellán Antonio del Cueto, imputado y encarcelado en Oviedo por haber cometido "varias locuras», dudándose "si eran ymboluntarias o si procedían de alguna malizia». Entre las acusaciones estaba el ausentarse de Cangas durante un largo periodo de tiempo, superior al estipulado en las constituciones, desatendiendo sus quehaceres eclesiásticos y obligando a nombrar excusador. El problema trascendió a lo económico, Cueto reivindicaba el cobro completo de su congrua y se negaba a que se le redujera para abonar al sustituto por orden de un auto del obispo. Por su parte, el clero colegial rechazaba hacerse cargo de las obligaciones de su compañero. EI caso se complicó cuando el provisor episcopal obligó a los capellanes cangueses a estar al cuidado de Cueto, dada su

${ }_{94}$ BUO, Toreno, caja 74, doc. 10: Consulta sobre la fundación de la misa del Alba (año 1740). supuesta enfermedad, quienes se habían negado por no estar entre sus tareas. El enviado de la diócesis reacciona abruptamente manteniendo a los eclesiásticos retenidos sin dejarles decir misa y amenazándoles con la excomunión y una multa si desobedecían su auto. Esto causó malestar y quejas al conde y éste se vio forzado a escribir al prelado de la diócesis, don Tomás José de Argüelles, absentista en el arcedianato de Benavente, quien hubo de disculparse ante el noble y rectificar el auto de su provisor, a quien insta para que templara la crispación que había provocado y evitar un nuevo roce con Toreno. Cuatro meses después, parece que se alcanza la paz según comunican los capellanes a don Fernando Ignacio..$^{95}$

No fue este el único capellán díscolo. Un decenio más tarde surgió otro: José de Miranda Rivera. El cruce de correspondencia implicó a la casa condal y al nuevo mitrado de Oviedo, don Juan de Avello. Las acusaciones eran semejantes a las de Cueto: no guardar la residencia y no asistir a sus obligaciones pastorales de modo reiterado y contumaz, además de otros «excesos voluntarios y culpables en que continuamente incurría, sin embargo de ser amonestado», lo que favoreció su prisión por el ordinario y que sus cargas fueran puestas en manos de otro excusador. El castigo de poco sirvió; tras su excarcelación reincidió en sus acciones. El conde hizo consulta jurídica si la mitad de su congrua debía ser transferida a su sustituto y la otra al resto del clero colegial; se «resolvió, por hombre docto, no debía percibir ningún [emolumento], y que el patrono no podía permitir se le pagasen». El consultado recomendó desposeer al capellán de su beneficio si insistía en marcharse de Cangas. Así sucedió: el clérigo se trasladó a su villa de origen, Avilés, fue suspendido e inhabilitado para celebrar misa y confesar. Esto sucedía en abril de 1738 y en diciembre fue restituido en sus funciones eclesiásticas, que no ejerció "por hallarse indispuesto»; falleció dos meses después. ${ }^{96}$

\section{CONCLUSIONES}

Desde el punto de vista honorífico, los Queipo se consolidaron en Cangas del Narcea con un patronato eclesiástico logrado a través de la compraventa y la donación en las parroquias de San Juan de Vega de Rengos y de Santa María de Gédrez, desde los albores del siglo xvı a los que hay que sumar los de Librán, Cerredo y Degaña, pertenecientes a los cotos jurisdiccionales de su propiedad. Las implicaciones fueron también económicas, pues los Toreno pudieron acceder a una parte de las rentas eclesiásticas a través de la percepción de diezmos, constituyendo una fuente más de financiación de su economía familiar. A estos títulos se sumó

95 BUO, Toreno, caja 69, docs. 18 [Consulta sobre un capellán enloquecido preso en Oviedo (sin fecha)], 19 [Copia de auto del provisor del obispado para nombrar excusador (Oviedo, 19-5-1724)], 20 [Correspondencia sobre auto del provisor obligando al clero de la colegiata de cuidar del capellán enloquecido: Rodrigo de Mon, en nombre de los capellanes de Cangas al conde de Toreno (Cangas, 22-7-1724); sendas cartas del obispo al conde de Toreno (Benavente, 4-8-1724); el obispo de Oviedo a su provisor y vicario general (Benavente, 25-8-1724); los capellanes de la colegiata al conde (Cangas, 18-10-1724)] y 27 [Auto del obispo (Oviedo, 9-5-1735)].

96 BUO, Toreno, caja 70, doc. 29: Consulta del conde de Toreno sobre los excesos del capellán José de Miranda (1735-1739). 
el privilegio que Felipe IV otorgó al arzobispo don Fernando de Valdés y Llano: el patronato de la iglesia parroquial de Santa María Magdalena de Cangas. El mal estado de conservación del templo le llevó a promocionar una nueva fábrica, el nuevo edificio obtuvo la categoría de colegiata y fue dotada con rentas para mantener a seis capellanes y un sacristán.

La fundación de nuevas capellanías y la herencia de otras por la anexión de varios mayorazgos favorecieron nuevos derechos, no solo en el Principado sino también en Madrid, en Sevilla y en La Rioja. Los herederos se vieron en la obligación de mantener y conservar estos privilegios, entre los que destacaba el derecho de presentación de los beneficios curados, simples y capellanías, dando lugar a una amplia y tupida red de relaciones clientelares. Las rentas no solo fueron disfrutadas por un bajo clero dependiente de la casa condal y sujeto a una rígida estructura jerárquica, sino también por algunos segundones de la familia como un medio de sustento al verse privados de la herencia del mayorazgo. En el fondo, subyacía un principio de solidaridad familiar.

La administración del patronato no estuvo exenta de conflictividad. Ésta tuvo lugar con otros vecinos por el control de los beneficios propios de Vega de Rengos y de Gédrez cuando aún no estaban consolidados por los Toreno, así como con el monasterio de Corias y el cabildo ovetense. La construcción de la colegiata canguesa supuso un contencioso con los Omaña, que verían desarticulados los derechos de los que se habían apropiado en la antigua parroquial. Los problemas también los suscitó la disminución de las rentas de la dotación de la fundación del arzobispo: los capellanes reivindican la reducción de sus cargas pastorales en compensación. Otros conflictos fueron causados por algunos beneficiados o bien por no atenerse a los estatutos de las fundaciones, o bien por reivindicar una mayor participación de las rentas eclesiásticas y diezmos.

\section{BibLIOgRAFÍA}

Álvarez Delgado, L. 2013. "Juegos de estrategia en los tribunales. Planteamientos tácticos entre partes litigantes a través de un proceso inquisitorial complejo del siglo XVI». Clío y Crimen 10 471-497.

Arroyo Vozmediano, J. L. 2008. «Iglesia, poder municipal y fundación de capellanías en Calahorra (1600-1710)». Revista de Historia Moderna 26: 189-220.

Atienza Hernández, I. 1990. «Pater familias, señor y patrón: oeconomía, clientelismo y patrón en el Antiguo Régimen», en R. Pastor (comp.), Relación de poder, de producción y parentesco en la Edad Media y Moderna: 411-458. Madrid: CSIC.

Atienza López, Á. 2008. "La apropiación de patronatos conventuales por nobles y oligarcas en la España moderna». Investigaciones Históricas 28: 79-116.

Atienza López, Á. 2009. "Fundaciones y patronatos conventuales y ascenso social en la España de los Austrias», en E. Soria Mesa, J. J. Bravo Caro y J. M. Delgado Barrado (eds.), Las élites en la época moderna: la monarquía española, vol. IV: 37-54. Córdoba: Universidad de Córdoba.

Atienza López, Á. 2010. «Nobleza, poder señorial y conventos en la España moderna. La dimensión política de las fundaciones nobiliarias», en E. Sarasa Sánchez y E. Serrano Martín (eds.), Estudios sobre señorío y feudalismo: homenaje a Julio Valdeón: 235-269. Zaragoza: Institución Fernando el Católico.

Avilés, T. de 1991. Armas y Linajes de Asturias y Antigüedades del Principado, edición, presentación y anexos de José M. GómezTabanera Oviedo: GEA.
Barrio Gozalo, M. 2001. «El sistema beneficial en la España del siglo XVIII. Pervivencias y cambios». Cuadernos Dieciochistas 2: 73-107.

Barrio Gozalo, M. 2010a. El clero en la España moderna. Córdoba: CajaSur. Obra Social y Cultural.

Barrio Gozalo, M. 2010b. El sistema beneficial de la Iglesia española en el Antiguo Régimen (1475-1834). Alicante: Universidad de Alicante.

Carrasco Martínez, A. 1997. «Participación de la aristocracia castellana en el mercado de deuda pública (juros)», en L. de Rosa y L. M. Enciso Recio (dirs.), Spagna e mezzogiorno d'Italia nell'eta della transizione. Tomo I. Stato, finanza ed econnomia (1650-1760): 313-331. Napoli: Edizioni Scientifiche Italiane.

Castillo Pintado, A. del. 1963. «Los juros de Castilla, apogeo y fin de un instrumento de crédito". Hispania 23: 43-70.

Catalán Martínez, E. 1999. «El precio del Purgatorio». Obradoiro de Historia Moderna 8: 31-63.

Catalán Martínez, E. 2000. El precio del Purgatorio. Los ingresos del clero vasco en la Edad Moderna. Bilbao: Universidad del País Vasco.

Catalán Martínez, E. 2004. «El derecho de patronato y el régimen beneficial de la Iglesia española en la Edad Moderna». Hispania Sacra 113: 135-167.

Catalán Martínez, E. 2015. «El clero rural vasco durante la Edad Moderna», en M.a R. Porres Marijuán (coord.), Entre el fervor y la violencia: estudios sobre los vascos y la Iglesia (siglos XVI-XVIII), 17-56. Bilbao: Universidad del País Vasco.

Clavero, B. 1989. Mayorazgo. Propiedad familiar en Castilla, 13691836. Madrid: Siglo XXI.

Corzo, R. y García, M. A. 2012. «El nacimiento de la arqueología cristiana en España durante el siglo XVIII», en M. Almagro-Gorbea J. Maier Allende (eds.), De Pompeya al Nuevo Mundo. La corona española y la arqueología en el siglo XVIII: 217-228. Madrid: Real Academia de la Historia-Patrimonio Nacional.

Díaz Álvarez, J. 2003. "Prestigio social del estamento nobiliario: el patronazgo eclesiástico asturiano de los Vigil de Quiñones en el siglo XVII». Revista de Historia Moderna 21: 261-290.

Díaz Álvarez, J. 2006a. Ascenso de una casa asturiana: los Vigil de Quiñones, marqueses de Santa Cruz de Marcenado. Oviedo: RIDEA.

Díaz Álvarez, J. 2006b. "Los marqueses de Valdecarzana, señores de vasallos en la Asturias del Antiguo Régimen (siglos XVI-XVIII)». Revista de Historia Moderna 24: 363-394.

Díaz Álvarez, J. 2008. La oligarquía urbana en el Oviedo de los Austrias. Oviedo: Universidad de Oviedo (Tesis Doctoral inédita).

Díaz Álvarez, J. 2009. «Estrategias de ascenso social de la hidalguía asturiana en los siglos XVI y XVII: el ejemplo de los Argüelles», en J. J. Bravo Caro y J. Sanz Sampelayo (eds.), Población y grupos sociales en el Antiguo Régimen, vol. I: 503-514. Málaga: Universidad de Málaga.

Díaz Álvarez, J. 2016. «Ascenso de la casa de Queipo: de la hidalguía al condado de Toreno». Obradoiro de Historia Moderna 25: 277-311.

Domínguez Ortiz, A. 1973. Las clases privilegiadas en el Antiguo Régimen. Madrid: Istmo.

Domínguez Ortiz, A. 2000. «Juros y censos en la Castilla del Seiscientos: una sociedad de rentistas», en A. M. Bernal (coord.), Dinero, moneda y crédito en la Monarquía Hispánica: 789-806. Madrid: Fundación ICO-Marcial Pons Historia.

Faya Díaz, M.a Á. 1992. Los señoríos eclesiásticos en la Asturias del siglo XVI. Oviedo: RIDEA.

Faya Díaz, M.a Á. 2003. «Gobierno municipal y venta de oficios en la Asturias de los siglos XVI y XVII». Hispania 213: 75-136.

Faya Díaz, M.a Á. 2007. «La oposición al poder señorial del monasterio de San Pelayo de Oviedo en el Coto de San Bartolomé de Nava», en I Congreso de Estudios Asturianos, Tomo III. Comisión de Historia, Geografía, Folclore y Etnografía: 29-42. Oviedo: RIDEA.

Faya Díaz, M.a Á. y Anes Fernández, L. 2007. Nobleza y poder en la Asturias del Antiguo Régimen. Oviedo: KRK Ediciones.

Fayard, J. 1982. Los miembros del consejo de Castilla, 1621-1746. Madrid: Siglo XXI.

Fernández Cubeiro, E. 1981. «Una práctica de la sociedad rural, aproximación al estudio de las capellanías de la diócesis compostelana en los siglo XVII y XVIII", en A. Eiras Roel et al., Historia social 
de Galicia en sus fuentes de protocolos: 205-215. Santiago de Compostela: Universidad de Santiago de Compostela.

Fernández García, P. 2015. «La familia Queipo de Llano: crecimiento e infancia en torno a la época del I conde de Toreno», en M. García Fernández (ed.), Familia, cultura material y formas de poder en la España moderna: 209-218. Madrid: Fundación Española de Historia Moderna.

Fernández Martín, L. 1974. «Una visita a las iglesias y monasterios asturianos de patronato real en 1613». Boletín del Instituto de Estudios Asturianos 82: 423-458.

Fernández Martín, L. 1977. «La iglesia de la Magdalena de Cangas de Narcea». Boletín del Real Instituto de Estudios Asturianos 90-91: 285-342.

Fernández Secades, L. 2009. Los Valdés. Una casa nobiliaria en el Gijón de los siglos XVI y XVII. Oviedo: KRK Ediciones.

Fernández Secades, L. 2011. La oligarquía gijonesa y el gobierno de la villa en el siglo XVIII. Gijón: Trea.

Floriano, A. 1957. "Cronología de los abades de Corias». Archivum. Revista de la Facultad de Filología 7: 271-291.

G. Novalín, J. L. 1968. El inquisidor general Fernando de Valdés. Su vida y su obra Oviedo: Universidad de Oviedo.

Gómez Álvarez, U. 1979. Estudio histórico de los préstamos censales del Principado de Asturias (1680-1715). Luarca: Bibliófilos Asturianos.

Gómez Álvarez, U. 1993. La sociedad tradicional asturiana. Oviedo: Universidad de Oviedo.

González Ramírez, S. 2007. Origen y descendencia de la ilustre casa de Merás. Tineo: Asociación Cultural «Conde de Campomanes».

González Ruiz, M. 1950. «Las capellanías españolas en su perspectiva histórica». Revista Española de Derecho Canónico 5: 475-501.

González Santos, J. 1992. "La iglesia de Santa María Magdalena de Cangas del Narcea. Puntualizaciones histórico-artísticas de un edificio singular del barroco asturiano». La Maniega 70: 1-12.

González Santos, J. 2014. «Aristócratas en vanguardia: las fundaciones y empresas artísticas de los Queipo de Llano en Asturias en el siglo XVII», en M.a Á. Faya Díaz (coord.), Las ciudades españolas en la Edad Moderna: oligarquías urbanas y gobierno municipal: $373-$ 425. Oviedo: KRK Ediciones.

Hernández, M. 1991. "La evolución de un delegado regio: corregi dores de Madrid en los siglos XVII y XVIII». Anuario de Historia de Derecho Español 61: 579-606.

Herreros Moya, G. J. 2012. "Así en la tierra como en el cielo. Aproximación al estudio de las capellanías en la Edad Moderna: entre la trascendencia y la política familiar. El caso de Córdoba». Historia y Genealogía 2: 111-141.

López Baamonde, M. 2007. Ascenso de una casa noble asturiana: Ios Queipo de Llano, condes de Toreno. Oviedo: Universidad de Oviedo (Trabajo de Investigación inédito).

López Baamonde, M. 2008. «Los Queipo de Llano, condes de Toreno: servicios a la monarquía», en M. a Á. Faya Díaz y E. Martínez-Radío (coords.), Nobleza y ejército en la Asturias de la Edad Moderna: 213-227. Oviedo: KRK Ediciones.

Miguélez, L. 1953. «Capellanías y fundaciones piadosas». Revista Ecclesia.

Morgado García, A. 1990. "Provisión de beneficios eclesiásticos en la diócesis de Cádiz durante el Antiguo Régimen (1700-1836)». Chronica Nova 18: 343-363.

Morgado García, A. 1996. El estamento eclesiástico y la vida espiritual en la diócesis de Cádiz en el siglo XVII. Cádiz: Universidad de Cádiz.
Orduña Portus, P. 2012. «Formas de religiosidad de la nobleza navarra en la Edad Moderna». Hispania Sacra 130: 583-622.

Presedo Garazo, A. 2014a. «La disputa entre el episcopado y la nobleza por los beneficios eclesiásticos en Galicia en el siglo XVI (14821598)». Revista Portuguesa de Historia XLV: 553-586.

Presedo Garazo, A. 2014b. «La preeminencia social de la nobleza gallega en el espacio sagrado durante los siglo XVI y XVII». Diversarum Rorum. Revista de los Archivos Catedralicio y Diocesano de Ourense y de los Amigos de la Catedral de Ourense 9: 409-431.

Pro Ruiz, J. 1989. «Las capellanías: familia y propiedad en el Antiguo Régimen». Hispania Sacra 84: 585-602.

Quintanal, I. 1983. La música en la catedral de Oviedo en el siglo XVIII. Oviedo: Centro de Estudios del Siglo XVIII.

Ramallo Asensio, G. 1998. «El particular caso de las capillas palaciegas en la arquitectura barroca asturiana», en Actas del VIIㅇ C.E.H.A.: 359-372. Murcia: Universidad de Murcia.

Ramos Cobano, C. 2011. «Las ordenaciones eclesiásticas como estrategia de perpetuación familiar: los Cepeda durante el siglo XVIII». Erebea 1: 397-418.

Roldán Pérez, A. 1974. "Gonzalo de Illescas y la Historia Pontifical», en Estudios literarios dedicados al profesor Mariano Baquero Goyanes: 575-638. Murcia: Universidad de Murcia.

Rubio Pérez, L. M. 2013. «Párrocos, parroquias y concejos: el modelo leonés en el marco de las comunidades rurales concejiles durante la Edad Moderna». Obradoiro de Historia Moderna 22: 129-166.

Saavedra, P. 2016. «El clero rural en la España moderna», en F. García González, G. Béaur y F. Boudjaaba (coords.), La historia rural en España y Francia (siglos XVI-XIX): contribuciones para una historia comparada y renovada, 385-412. Madrid: Sociedad Española de Historia Agraria.

Saavedra, P., H. Sobrado Correa y A. Presedo Garazo. 2013. «La red parroquial y el clero rural en la Galicia de los siglos XVI-XIX: resultados de una investigación en curso». Obradoiro de Historia Moderna 22: 93-128.

Sobaler Seco, M. a Á. 1987. Los colegiales mayores de Santa Cruz (14841670): una élite de poder. Valladolid: Junta de Castilla y León.

Sobaler Seco, M.a Á. 2003. "Colegiales de Santa Cruz: condición social y familiar (la estrategia familiar del bando asturiano en el Colegio Mayor de Valladolid)», en Aulas y saberes, vol. II: 461-476. Valencia: Universitat de València.

Soria Mesa, E. 2000. "Los estudios sobre las oligarquías municipales en la Castilla moderna. Un balance en claroscuro». Manuscrits 18 185-197.

Soria Mesa, E. 2002. "Las capellanías en la Castilla moderna: familia y ascenso social», en A. Irigoyen López y A. L. Pérez Ortiz (eds.), Familia, transmisión y perpetuación (siglos XVI-XIX): 135-148. Murcia: Universidad de Murcia.

Toboso Sánchez, P. 1987. La deuda pública castellana durante el Antiguo Régimen (juros) y su liquidación en el siglo XIX. Madrid: Instituto de Estudios Fiscales.

Tolivar Faes, J. R. 1966. Hospitales de leprosos en Asturias en las edades Media y Moderna. Oviedo: IDEA.

Toreno, Conde de. 2003. Discursos parlamentarios, estudio preliminar y selección de los discursos J. Varela Suanzes-Carpegna. Oviedo: Junta General del Principado de Asturias.

Varela Suanzes-Carpegna, J. 2005. El conde de Toreno (1786-1843): biografía de un liberal. Madrid: Marcial Pons Historia. 